Prepared in cooperation with the City of Independence, Missouri, Water Department

\title{
Groundwater Monitoring Plan for the Missouri River Alluvial Aquifer in the Vicinity of the City of Independence, Missouri, Well Field
}

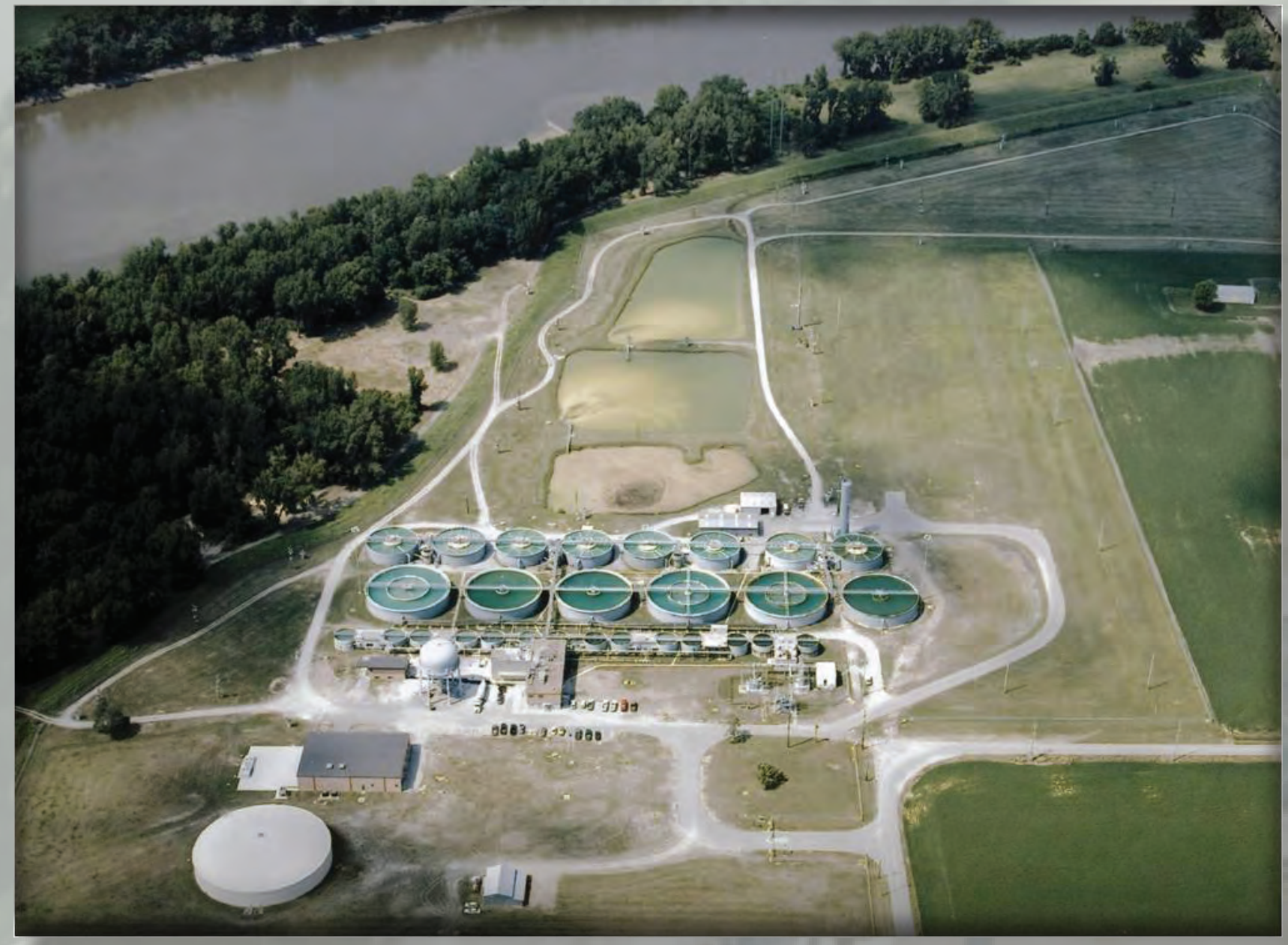

Scientific Investigations Report 2012-5050 
Cover photograph. City of Independence, Missouri water treatment plant and Missouri River, 2011. Photograph courtesy of the City of Independence, Missouri Water Department. 


\section{Ground water Monitoring Plan for the Missouri River Alluvial Aquifer in the Vicinity of the City of Independence, Missouri, Well Field}

By Donald H. Wilkison

Prepared in cooperation with the City of Independence, Missouri, Water Department

Scientific Investigations Report 2012-5050 


\section{U.S. Department of the Interior \\ KEN SALAZAR, Secretary \\ U.S. Geological Survey \\ Marcia K. McNutt, Director}

U.S. Geological Survey, Reston, Virginia: 2012

For more information on the USGS — the Federal source for science about the Earth, its natural and living resources, natural hazards, and the environment, visit http://www.usgs.gov or call 1-888-ASK-USGS.

For an overview of USGS information products, including maps, imagery, and publications, visit http://www.usgs.gov/pubprod

Any use of trade, product, or firm names is for descriptive purposes only and does not imply endorsement by the U.S. Government.

Although this report is in the public domain, permission must be secured from the individual copyright owners to reproduce any copyrighted materials contained within this report.

Suggested citation:

Wilkison, D.H., 2011, Groundwater monitoring plan for the Missouri River alluvial aquifer in the vicinity of the City of Independence, Missouri, well field: U.S. Geological Survey Scientific Investigations Report 2012-5050, 35 p. 


\section{Contents}

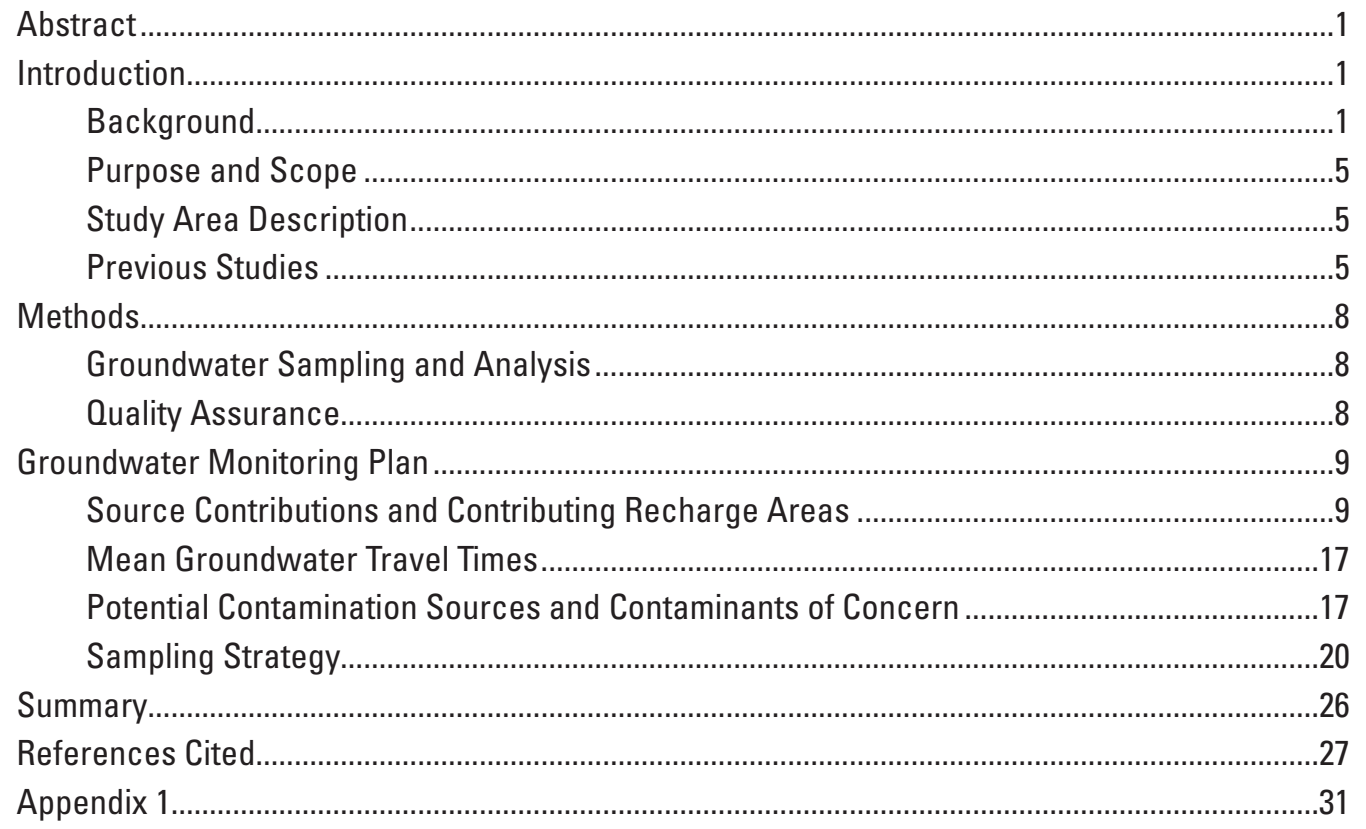

\section{Figures}

1. Map showing study area and location of City of Independence well field in relation to regional groundwater flow model.

2. Map showing $A$, Mean water-level altitude and $B$, contributing recharge area and mean groundwater travel times within the contributing recharge area for the City of Independence well field

3. Map showing location of monitoring wells and primary potential sources of contamination in relation to the Independence well field.

4. Population, and projected population growth, for the greater Kansas City metropolitan area and selected counties within the area from 1970 through 2030 (Mid-America Regional Council, 2004) and mean daily well pumpage from the Independence well field

5. Graphs showing triclosan quality assurrance samples using immonassay method, 2008 through 2010. $A$, Predicted versus measured triclosan concentrations by immunoassay; $B$, comparison of laboratory and field replicate sample concentrations; and $C$, analytical method comparison sample.

6. Graph showing mean water level in monitoring wells sampled from 1997 through 2010 and relation to mean annual Missouri River discharge

7. Graphs showing mean percent Missouri River or land-surface contributions to recharge in study area monitoring wells 
8. Piper diagram based upon $A$, mean percent Missouri River contribution to monitoring well; and $B$, geographic location.

9. Boxplots showing calcium, chloride, and sodium concentrations in water samples collected from December, 1997 through December, 2010

10. Graph showing $\delta_{18} 0 x y g$ en and $\delta$ deuterium values for the Missouri River, Independence supply wells, and groundwater within the Independence well field contributing recharge area.

11. Boxplots showing ammonia, nitrite plus nitrate concentrations, and mean percent of total nitrogen in water samples collected from December, 1997 through December, 2010

12. Graphs showing average groundwater travel times from monitoring well contributing recharge areas to monitoring wells and from monitoring wells to the nearest supply well.

13. Graphs showing chloride $(A$ and $B)$ and pesticide concentrations $(C$ and $D)$ by month and by discharge in water samples from the Missouri River collected from October, 1997 through December, 2010.

14. Graphs showing specific conductance values in wells located north of the Missouri River and with more than 50-year travel times.

15. Graphs showing $A$, Relation between triclosan concentration and organic wastewater, and $B$, pharmacuetical concentrations in water samples collected from the Blue River Basin, 1998 through 2010.

\section{Tables}

1 Monitoring well identifier, location, and primary potential contamination sources ..........4

2. Average percent detection of agricultural chemicals (atrazine and alachlor) by enzyme-linked immunosorbent assay for water samples collected between 1999 through 2009

3. Groundwater sampling frequency for the Independence well field.

4. Associated field and laboratory analysis for monitoring wells and sampling reccurrence interval (in years). 


\section{Conversion Factors}

SI to Inch/Pound

\begin{tabular}{lcl}
\hline \multicolumn{1}{c}{ Multiply } & By & \multicolumn{1}{c}{ To obtain } \\
\hline centimeter $(\mathrm{cm})$ & Length & \\
meter $(\mathrm{m})$ & 0.3937 & inch (in.) \\
kilometer $(\mathrm{km})$ & 3.281 & foot (ft) \\
\hline & .6214 & mile (mi) \\
\hline square kilometer $\left(\mathrm{km}^{2}\right)$ & Area & \\
square kilometer $\left(\mathrm{km}^{2}\right)$ & 247.1 & acre \\
\hline & .3861 & square mile (mi $)$ \\
\hline cubic meter $\left(\mathrm{m}^{3}\right)$ & Volume & \\
& 6.290 & barrel (petroleum, 1 barrel equals 42 \\
liter $(\mathrm{L})$ & & gallons) \\
liter $(\mathrm{L})$ & 1.057 & quart (qt) \\
cubic meter $\left(\mathrm{m}^{3}\right)$ & .2642 & gallon (gal) \\
cubic meter $\left(\mathrm{m}^{3}\right)$ & 264.2 & gallon (gal) \\
cubic meter $\left(\mathrm{m}^{3}\right)$ & .0002642 & million gallons $(\mathrm{Mgal})$ \\
\hline & 35.31 & cubic foot (ft $)$ \\
\hline cubic meter per second $\left(\mathrm{m}^{3} / \mathrm{s}\right)$ & Flow rate & \\
cubic meter per day $\left(\mathrm{m}^{3} / \mathrm{d}\right)$ & 35.31 & cubic foot per second $\left(\mathrm{ft}^{3} / \mathrm{s}\right)$ \\
\hline kilogram $(\mathrm{kg})$ & 264.2 & gallon per day (gal/d) \\
\hline
\end{tabular}

Temperature in degrees Celsius $\left({ }^{\circ} \mathrm{C}\right)$ may be converted to degrees Fahrenheit $\left({ }^{\circ} \mathrm{F}\right)$ as follows:

$$
{ }^{\circ} \mathrm{F}=\left(1.8 x^{\circ} \mathrm{C}\right)+32
$$

Vertical coordinate information is referenced to the insert datum name (and abbreviation) here, for instance, "North American Vertical Datum of 1988 (NAVD 88)"

Horizontal coordinate information is referenced to the insert datum name (and abbreviation) here, for instance, "North American Datum of 1983 (NAD 83)"

Altitude, as used in this report, refers to distance above the vertical datum.

Specific conductance is given in microsiemens per centimeter at 25 degrees Celsius $(\mu \mathrm{S} / \mathrm{cm}$ at $\left.25^{\circ} \mathrm{C}\right)$.

Concentrations of chemical constituents in water are given either in milligrams per liter (mg/L) or micrograms per liter ( $\mu \mathrm{g} / \mathrm{L})$. 



\title{
Groundwater Monitoring Plan for the Missouri River Alluvial Aquifer in the Vicinity of the City of Independence, Missouri, Well Field
}

\author{
By Donald H. Wilkison
}

\section{Abstract}

Source contributions to monitoring and supply wells, contributing recharge areas, groundwater travel times, and current (2012) understanding of alluvial water quality were used to develop a groundwater monitoring plan for the Missouri River alluvial aquifer in the vicinity of the City of Independence, Missouri well field. The plan was designed to evaluate long-term alluvial water quality and assess potential changes in, and threats to, well-field water quality. Source contributions were determined from an existing groundwater flow model in conjunction with particle-tracking analysis and verified with water-quality data collected from 1997 through 2010 from a network of 68 monitoring wells. Three conjunctive factors - well-field pumpage, Missouri River discharge, and aquifer recharge-largely determined groundwater flow and, therefore, source contributions. The predominant source of groundwater to most monitoring wells and supply wells is the Missouri River, and this was reflected, to some extent, in alluvial water quality. To provide an estimate of the maximum potential lead time available for remedial action, monitoring wells where groundwater travel times from the contributing recharge areas are less than 2 years and predominately singular sources (such as the Missouri River or the land surface) were selected for annual sampling. The sample interval of the remaining wells, which have varying travel times and intermediate mixtures of river and land-surface contributions, were staggered on a 2-, 3-, or 4-year rotation. This was done to provide data from similar contributing areas and account for inherent aquifer variability yet minimize sample redundancy.

\section{Introduction}

The City of Independence supplies water from wells completed in the Missouri River alluvial aquifer to approximately 250,000 eastern Jackson County, Missouri residents. Concerns about potential threats to this water supply prompted the U.S. Geological Survey (USGS), in cooperation with the City of Independence (herein after referred to as
Independence), to establish a network of monitoring wells surrounding the Independence well field. The wells were installed in 1997 and 1998 and since then have been used to evaluate regional groundwater flow, aquifer properties and water quality (Kelly and Blevins, 1995; Kelly, 1996a, 1996b, 2002a; Kelly and Rydlund, 2006), and to aid in development of a groundwater monitoring plan (Kelly, 2002b). A more recent study (Kelly, 2010) indicated pumpage from new supply wells and altered pumpage from older supply wells had changed groundwater flow, aquifer travel times, and the contributing recharge area (CRA) of the well field. The CRA delineates the two-dimensional surficial extent of aquifer recharge and illustrates potential areas of contamination to the aquifer and, subsequently, the well field (Reilly and Pollock, 1993). The zone of contribution (ZOC) is the three-dimensional volume of water that flows to a well from within the CRA (Morrissey, 1989). However, the groundwater monitoring plan (Kelly, 2002b) had not been revised to reflect renewed understanding of the system. The updated sampling plan in this report provides a framework for long-term water-quality assessment and identifies potential aquifer contamination sources within the CRA and the ZOC of the Independence well field.

\section{Background}

A groundwater flow model, calibrated to transient conditions using quasi-steady state initial conditions of mean annual river stage, mean annual precipitation, and 2007 pumpage from the Independence well field (fig.1), has been developed (Kelly, 2010). The CRA of the well field was delineated from the flow model (fig. 2). Additionally, groundwater travel times to monitoring wells and from monitoring wells to supply wells within the CRA were determined. Although the aquifer commonly extends to a depth of more than 25 meters, plan views (figs. 1 and 2) only reflect the two-dimensional surficial component of the alluvial aquifer within the study area. A calibrated groundwater flow model is designed to capture the complexity of three-dimensional flow.

Additionally, a groundwater monitoring network (fig 1; table 1), comprised of 68 wells in 29 well nests, is located 

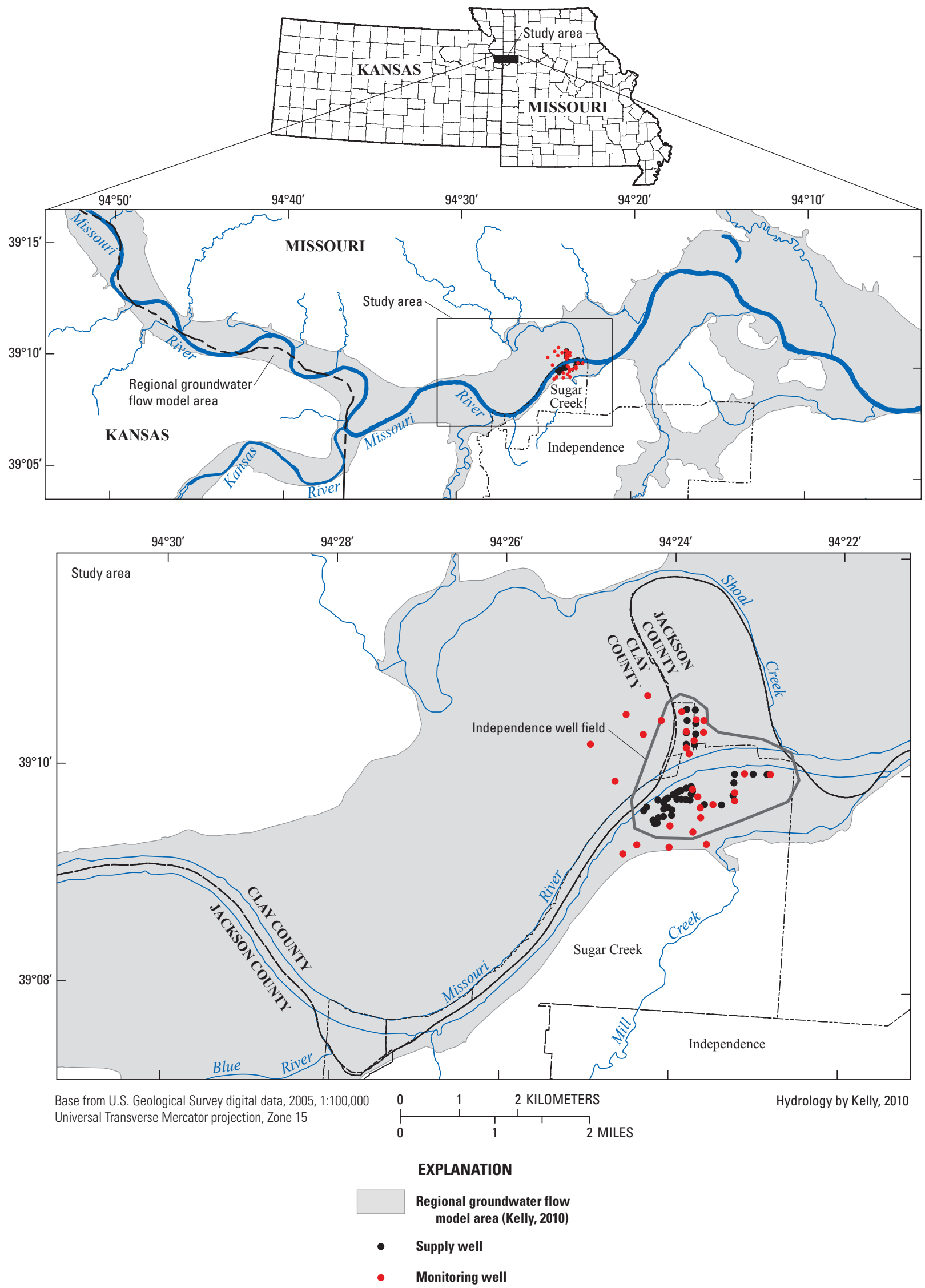

Figure 1. Study area and location of City of Independence well field in relation to regional groundwater flow model. 

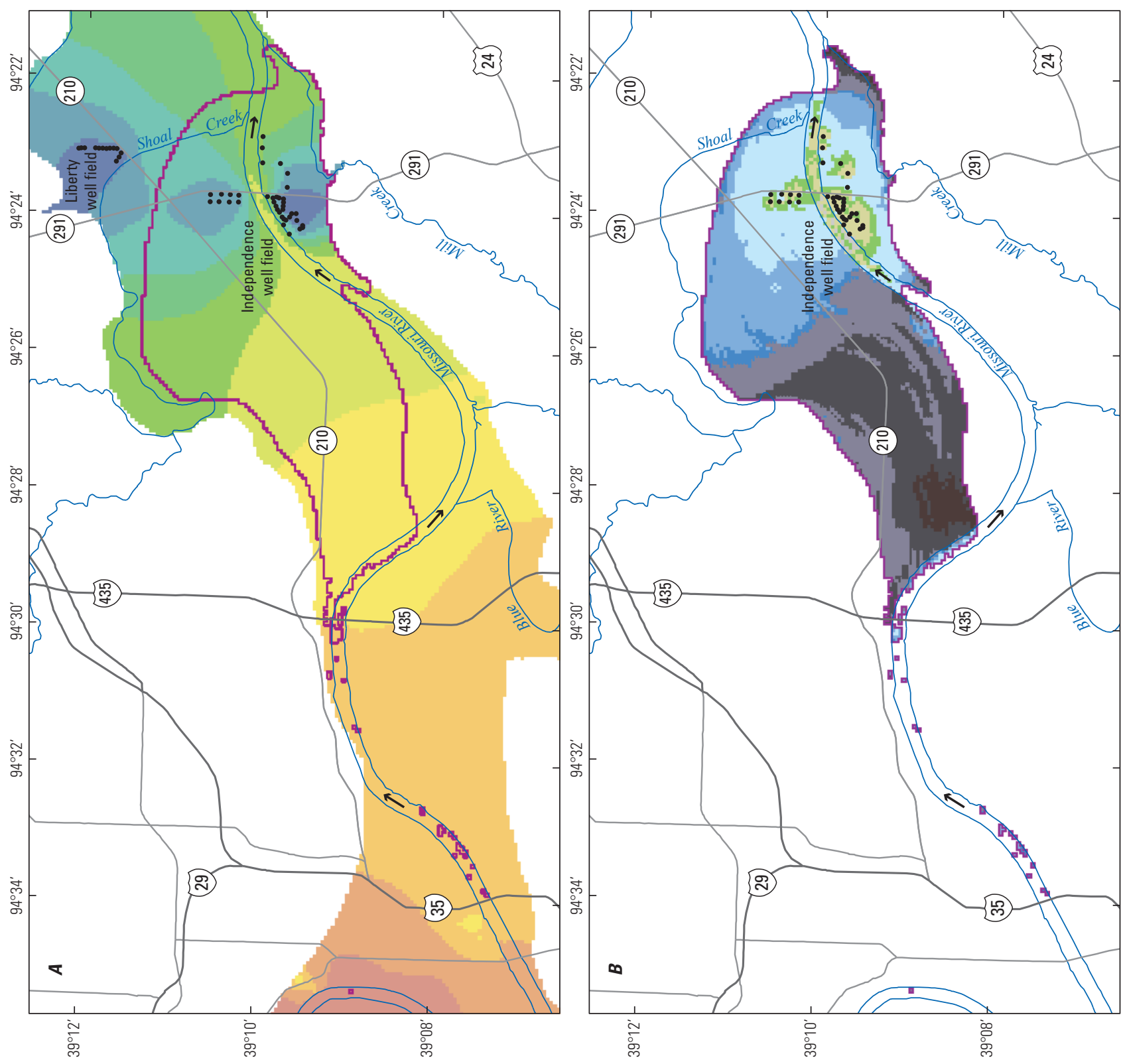
Table 1. Monitoring well identifier, location, and primary potential contamination sources (updated from Kelly, 2010).

[UTM, Universal Transverse mercator; m, meter; W, water way; A, agricultural; U, urban; RR, railroad; H, highway; I, industrial; L, landfill; --, not applicable]

\begin{tabular}{|c|c|c|c|c|c|c|c|}
\hline \multicolumn{4}{|c|}{ Wells south to the Missouri River } & \multicolumn{4}{|c|}{ Wells north to the Missouri River } \\
\hline $\begin{array}{l}\text { Monitoring } \\
\text { well } \\
\text { identifier }\end{array}$ & $\begin{array}{c}\text { East-West } \\
\text { UTM coordinate } \\
(\mathrm{m})\end{array}$ & $\begin{array}{l}\text { North-South } \\
\text { UTM coordinate } \\
\text { (m) }\end{array}$ & $\begin{array}{c}\text { Primary } \\
\text { potential } \\
\text { contamination } \\
\text { sources }\end{array}$ & $\begin{array}{c}\text { Monitoring } \\
\text { well } \\
\text { identifier }\end{array}$ & $\begin{array}{l}\text { East-West } \\
\text { UTM coordinate } \\
\text { (m) }\end{array}$ & $\begin{array}{l}\text { North-South } \\
\text { UTM coordinate } \\
\text { (m) }\end{array}$ & $\begin{array}{c}\text { Primary } \\
\text { potential } \\
\text { contamination } \\
\text { sources }\end{array}$ \\
\hline $1 \mathrm{a}$ & 378188.531 & 4334787.000 & $\mathrm{~W}$ & $16 \mathrm{a}$ & 378092.313 & 4335856.500 & $\mathrm{~W}$ \\
\hline $1 \mathrm{~b}$ & 378188.531 & 4334787.000 & $\mathrm{~W}$ & $16 b$ & 378092.313 & 4335856.500 & $\mathrm{~W}, \mathrm{~A}, \mathrm{U}$ \\
\hline $2 b$ & 378546.094 & 4334866.000 & $\mathrm{~W}$ & $17 b$ & 379089.688 & 4336261.000 & $\mathrm{~W}$ \\
\hline $3 a$ & 378809.594 & 4334756.500 & $\mathrm{~W}, \mathrm{~A}, \mathrm{RR}, \mathrm{H}$ & $18 \mathrm{a}$ & 379129.500 & 4336421.500 & $\mathrm{~W}$ \\
\hline $3 b$ & 378809.594 & 4334756.500 & $\mathrm{~W}, \mathrm{~A}, \mathrm{RR}, \mathrm{H}$ & $18 b$ & 379129.500 & 4336421.500 & $\mathrm{~W}$ \\
\hline $4 \mathrm{a}$ & 379026.313 & 4335095.500 & $\mathrm{~W}, \mathrm{~A}, \mathrm{RR}$ & $19 \mathrm{a}$ & 379438.188 & 4336544.500 & $\mathrm{~W}$ \\
\hline $4 \mathrm{~b}$ & 379026.313 & 4335095.500 & $\mathrm{~W}$ & $19 b$ & 379438.188 & 4336544.500 & $\mathrm{~W}, \mathrm{~A}, \mathrm{H}, \mathrm{I}$ \\
\hline $6 a$ & 379645.688 & 4334787.000 & $\mathrm{~W}$ & $21 b$ & 379602.781 & 4336684.000 & $\mathrm{~A}, \mathrm{~W}$ \\
\hline $7 \mathrm{a}$ & 379430.625 & 4335234.500 & $\mathrm{~W}, \mathrm{~A}$ & $21 \mathrm{c}$ & 379602.781 & 4336684.000 & $\mathrm{~A}, \mathrm{~W}$ \\
\hline $7 \mathrm{~b}$ & 379430.625 & 4335234.500 & $\mathrm{~W}, \mathrm{~A}$ & $22 \mathrm{a}$ & 379430.656 & 4336891.000 & W \\
\hline $7 \mathrm{c}$ & 379430.625 & 4335234.500 & $\mathrm{~W}, \mathrm{~A}$ & $22 b$ & 379430.656 & 4336891.000 & A, H, I \\
\hline $8 \mathrm{a}$ & 379432.031 & 4335442.000 & $\mathrm{~W}, \mathrm{~A}, \mathrm{H}$ & $22 c$ & 379430.656 & 4336891.000 & A, H, I \\
\hline $8 \mathrm{~b}$ & 379432.031 & 4335442.000 & $\mathrm{~W}, \mathrm{~A}, \mathrm{H}$ & $23 a$ & 379610.250 & 4336890.500 & W \\
\hline $9 \mathrm{a}$ & 379515.969 & 4335633.000 & W & $23 b$ & 379610.250 & 4336890.500 & W \\
\hline $9 b$ & 379515.969 & 4335633.000 & W & $23 c$ & 379610.250 & 4336890.500 & W \\
\hline $11 \mathrm{c}$ & 379758.563 & 4335462.000 & $\mathrm{~W}, \mathrm{~A}$ & $26 a$ & 378279.125 & 4336991.500 & $\mathrm{~W}, \mathrm{U}, \mathrm{A}, \mathrm{H}, \mathrm{I}$ \\
\hline $12 \mathrm{a}$ & 380130.781 & 4335520.500 & W & $26 b$ & 378279.125 & 4336991.500 & $\mathrm{~W}, \mathrm{U}, \mathrm{A}, \mathrm{H}, \mathrm{I}$ \\
\hline $12 b$ & 380130.781 & 4335520.500 & W & $27 \mathrm{a}$ & 377677.906 & 4336483.500 & $\mathrm{~W}, \mathrm{U}, \mathrm{A}, \mathrm{H}, \mathrm{I}$ \\
\hline $13 \mathrm{a}$ & 380128.500 & 4335659.500 & W & $27 b$ & 377677.906 & 4336483.500 & $\mathrm{U}, \mathrm{A}, \mathrm{I}$ \\
\hline $13 b$ & 380128.500 & 4335659.500 & W & $28 \mathrm{a}$ & 379020.000 & 4337100.000 & $\mathrm{~W}, \mathrm{~L}, \mathrm{~A}, \mathrm{U}$ \\
\hline $14 \mathrm{a}$ & 380299.125 & 4335984.500 & W & $28 b$ & 379020.000 & 4337100.000 & $\mathrm{~A}, \mathrm{~L}, \mathrm{U}$ \\
\hline $14 b$ & 380299.125 & 4335984.500 & W & $29 a$ & 378512.000 & 4336861.000 & $\mathrm{~W}, \mathrm{~L}, \mathrm{~A}, \mathrm{U}$ \\
\hline $14 \mathrm{c}$ & 380299.125 & 4335984.500 & W & $29 b$ & 378512.000 & 4336861.000 & $\mathrm{~W}, \mathrm{~L}, \mathrm{~A}, \mathrm{U}$ \\
\hline $15 \mathrm{a}$ & 380965.906 & 4335972.000 & $\mathrm{~W}$ & -- & -- & -- & -- \\
\hline $15 \mathrm{~b}$ & 380965.906 & 4335972.000 & W & -- & -- & -- & -- \\
\hline
\end{tabular}


within the 10-year ZOC to the Independence well field. The 10 -year ZOC, herein after referred to as the ZOC, refers to the three-dimensional volume of water with groundwater flow times to supply wells of 10 years or less. Samples collected from these wells have been used to describe water-quality conditions within the aquifer from 1997 through 2008 (Kelly, 2002a, 2002b, 2010; Kelly and Rydlund, 2006). Located within the ZOC are a number of potential sources of contamination (fig. 3; table 1), identified from the intersection and proximity of CRAs with major water ways, highways, and urban and agricultural land uses (Kelly, 2010). Potential sources also include permitted hazardous waste, Superfund and National Pollution Discharge Elimination System (NPDES) facilities, mining operations, and municipal wastewater treatment facilities (Kelly, 2010). Additionally, increasing commercial and residential development in the region and proposed expansion to major transportation corridors have led to concerns that such contaminant sources ultimately could affect aquifer and public-supply well water quality.

\section{Purpose and Scope}

This report describes a groundwater monitoring plan for the Missouri River alluvial aquifer in the vicinity of the City of Independence, Missouri well field. The sampling strategy was designed to assess long-term water quality and provide data necessary to evaluate temporal and spatial changes to water quality. This report supports groundwater protection activities and provides resource managers and the public with information needed to develop a long-term groundwater protection plan and identify potential threats to alluvial aquifer water quality, especially important because groundwater treatment can be expensive and contamination difficult to alleviate (Taylor and Alley, 2001).

\section{Study Area Description}

Independence, Missouri operates a water-supply well field in the eastern part of Jackson County, Missouri. The water-supply well field comprises 41 wells (fig. 1) completed in the Missouri River alluvial aquifer. The water-supply wells are located north and south of the Missouri River and together supply, on average, 29 million gallons of water per day for approximately 250,000 residents of Independence and surrounding communities (Missouri Department of Natural Resources, 2009a). In general, groundwater flows from west to east in the alluvial aquifer within the study area; however, a cone of depression caused by well-field pumpage along the eastern well-field boundary alters the direction of groundwater flow toward areas where supply wells are concentrated (fig. 2A). In general, the CRA for the Independence well field covers an area of approximately 40 square kilometer (sq km), elongated in a westerly direction, with the western boundary primarily defined by the Missouri River, the northern and southern boundaries primarily determined by the extent of the alluvial valley walls, and the eastern most boundary constrained by pumping effects from the Liberty and Independence well fields (figs. $2 A$ and $2 B$ ).

Land use in the CRA is largely agricultural with lesser amounts of urban land. The urban land is a mixture of residential, commercial, and industrial development with resultant impervious surfaces. The proximity of four (active and closed) landfills, mine stabilization and solid-waste land application projects, arterial transportation corridors (highway, train, and large river) to the well field provides concern about potential contamination of source waters (fig. 3; Kelly, 2010).

Since 1970, decadal population increases within the region have been about 10 percent with similar increases projected for several future decades (fig. 4; Mid-America Regional Council, 2004). In response to such growth and increased water demand, the number of water-supply wells operated by Independence increased from 33 in 1996 to 40 in 2007 (Kelly, 1996a; 2010; Missouri Department of Natural Resources, 2009a). This resulted in increased pumpage and groundwater withdrawals from the Missouri River alluvial aquifer (fig. 4). Pumpage from the Independence and Liberty well fields have resulted in widespread cones of depression that extend throughout much of the eastern one-third of the study area (fig. $2 A$ ).

The primary source of surface-water recharge to the alluvial aquifer is the Missouri River and, to a much lesser extent, tributaries to the Missouri River, including the Kansas River, Blue River, Mill Creek, and Shoal Creek (fig. 1). Missouri River recharge consists of natural and induced (from well pumpage) recharge. Although the area typically receives more than 100 centimeters $(\mathrm{cm})$ of precipitation in any given year (the 30 -year average is $109 \mathrm{~cm}$; Christensen and others, 2010), infiltration, on average, accounts for less than 1 percent of aquifer recharge compared to the amount that originates from river leakage (Kelly, 2010).

\section{Previous Studies}

Missouri River alluvial aquifer properties within the study area were described by Emmett and Jeffrey (1969). The general geologic setting of the study area was described by Hasan and others (1988) with more detailed descriptions of the Missouri River alluvial valley provided by Gentile and others (1994). Additional studies detailing the aquifer physical properties, potentiometric surface maps, groundwater flow, and contributing recharge areas were published by Kelly and Blevins (1995) and Kelly (1996a).

Kelly (1996b) developed a long-term (10-year) groundwater sampling plan for the CRA of the Independence well field using simulated groundwater flow paths (Kelly, 1996a). The simulation evaluated five river-stage/well-pumping scenarios: (1) low river stage and low pumpage; (2) high river stage and low pumpage; (3) average river stage and pumpage; (4) low river stage and high pumpage; and (5) high river stage and high pumpage. River stages represented the period 1958 


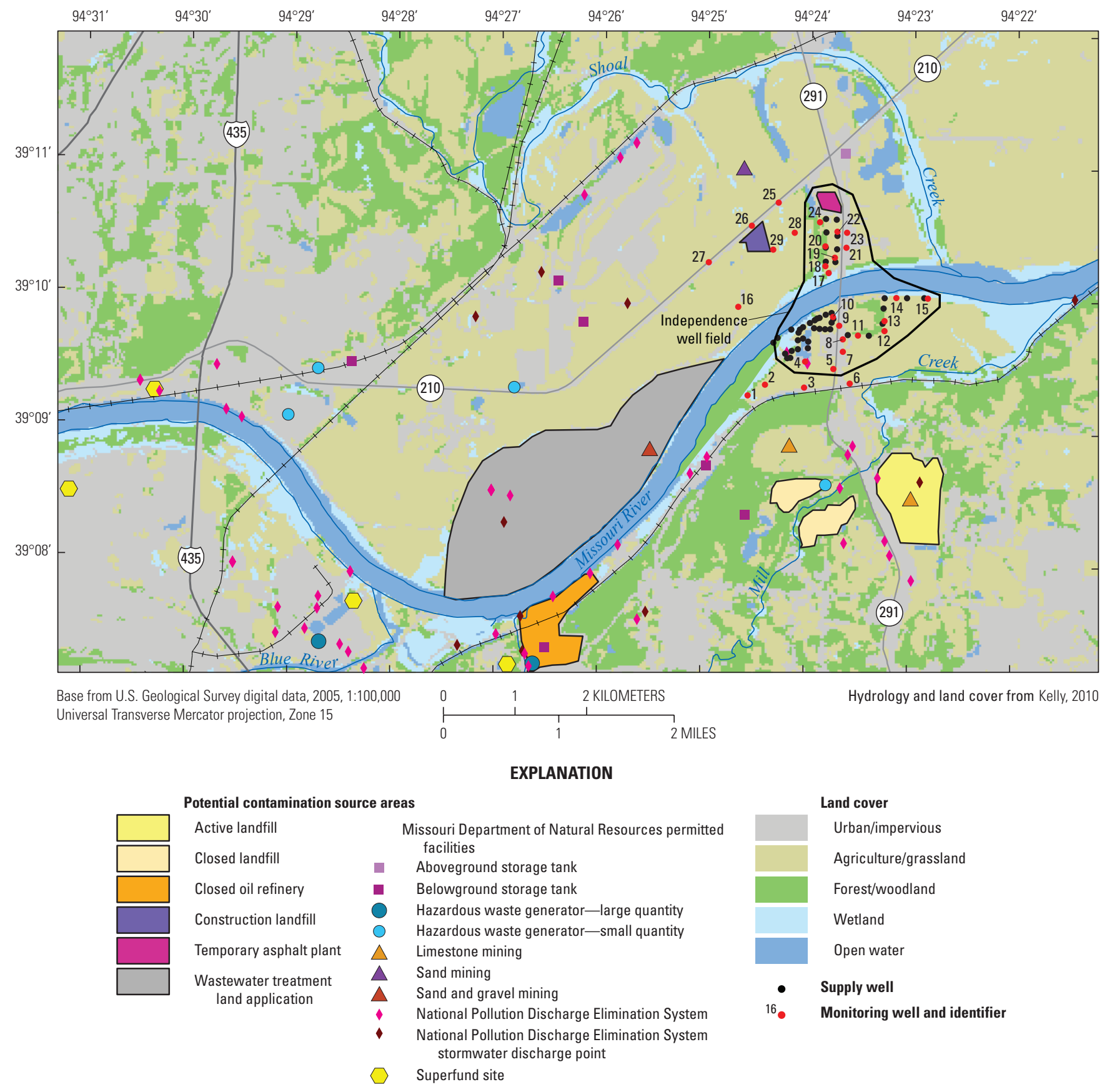

Figure 3. Location of monitoring wells and primary potential sources of contamination in relation to the Independence well field. 

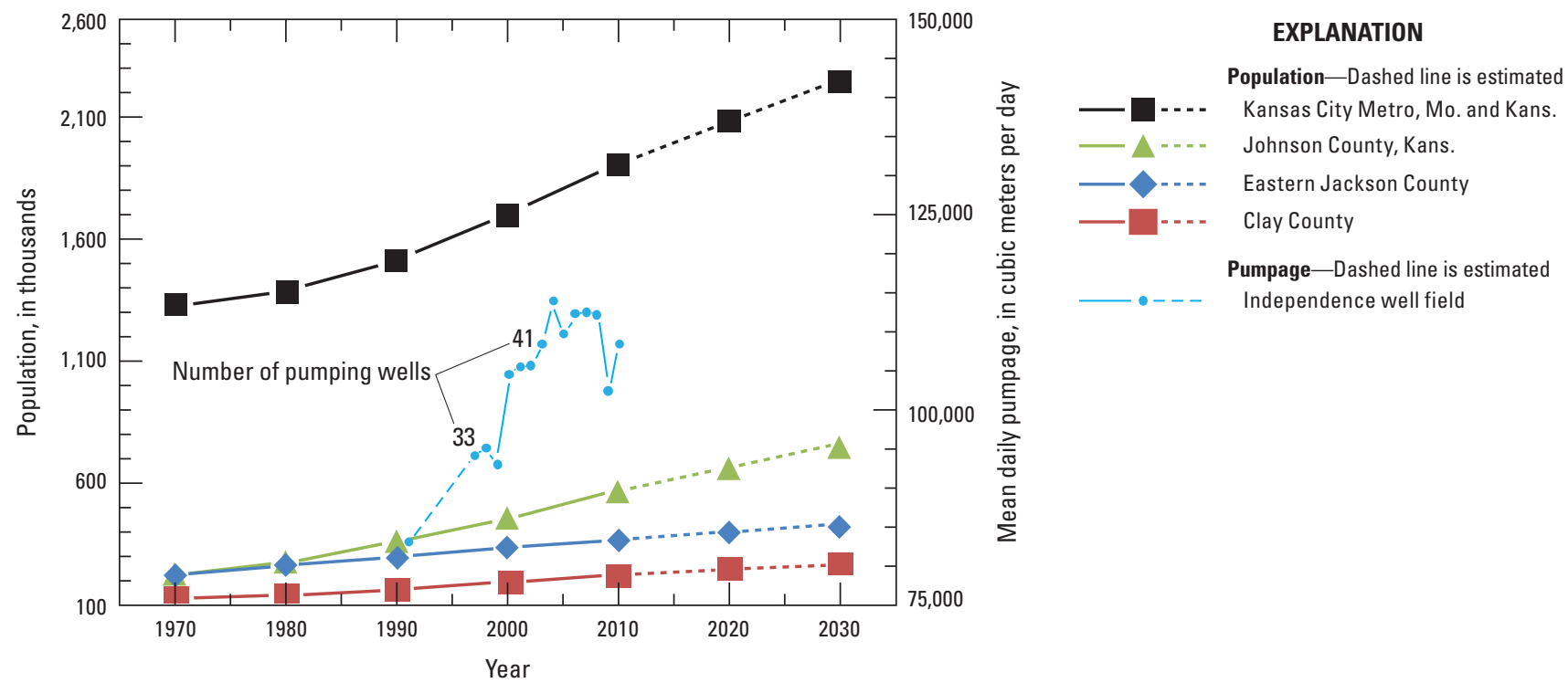

Figure 4. Population, and projected population growth, for the greater Kansas City metropolitan area and selected counties within the area from 1970 through 2030 (Mid-America Regional Council, 2004) and mean daily well pumpage from the Independence well field (Kelly, 1996a; 2010; City of Independence). [Eastern Jackson County includes entirety of county excepting the cities of Kansas City and Grandview, Mo.]

through 1994 and pumping rates were based on mean 1994 rates. Simulation results from the river-stage/well-pumping scenarios determined that the proximity of a pumping well to the Missouri River or alluvial valley wall played a large role in defining the shape of the CRA to supply wells. Wells proximate to the river had much smaller recharge areas and much shorter groundwater travel times than wells located near valley walls (Kelly, 1996a).

A sampling plan, designed to assess seasonal variation of water quality related to agricultural chemical usage within the CRA, was implemented from 1997 to 2000 (Kelly, $2002 \mathrm{~b}$ ). One-third of the wells sampled had low (near the limit of quantification), but detectable concentrations of alachlor, 14 percent had detectable concentrations of atrazine, and 8 percent had detectable concentrations of benzene, toluene, ethyl benzene, and xylene (herein after referred to as BTEX). The largest concentrations of alachlor, atrazine, and nutrients (dissolved ammonia, nitrite plus nitrate, and orthophosphorus) occurred in the shallowest wells; however seasonal variability was not well defined. These concentration data indicated that although contributions of some chemicals likely originated at the land surface, other factors, such as induced river recharge, also may have contributed to the results (Kelly, 2002b).

A follow-up study (Kelly, 2002b) used groundwater flow simulation and isotopic mixing models to determine that most groundwater in the alluvial aquifer originated in the Missouri River and traveled less than 25 years through the aquifer to the pumping well. The models indicated that precipitation and flow, which originated outside the ZOC, each contributed less than 10 percent of well-field recharge.

Kelly and Rydlund (2006) examined how riverbank filtration between the Missouri River and the pumping wells affected groundwater quality. These data indicated that riverbank filtration resulted in order(s) of magnitude removal of bacteria and viruses from the Missouri River as groundwater flowed to supply wells.

More recently, Kelly (2010) used simulated steady-state groundwater flow and particle-tracking analysis to determine CRAs for the supply wells for 2007 conditions of well pumpage and mean annual river discharge and aquifer recharge. This simulation updated a previous flow model (Kelly, 1996a) by decreasing cell size by one-half and increasing the number of active cells by a factor of more than four. Updates to the model were based on additional depth to bedrock data, channel bathymetry data collected in 2007, additional supply-well data, and a more than 10-fold increase in the number of waterlevel observations available for the transient calibration (Kelly, 2010). Groundwater travel times within the CRA to monitoring wells ranged from less than 1 to more than 1,500 years. Travel times from monitoring wells to supply wells ranged from less than 1 day to 32 years (Kelly, 2010).

Nonpoint source contributions to study area streamsespecially the Blue River, an upstream tributary from the Missouri River - have been documented (Wilkison and others, 2002; 2006; 2009; Rasmussen and others, 2009). These studies demonstrated that a myriad of contaminants, including bacteria, nutrients, and a variety of urban microconstituents including polycyclic aromatic hydrocarbons, as well as compounds related to household and industrial chemicals frequently are discharged to the Missouri River. Urbanization has led to biological and ecological degradation at stream sites within the study area (Wilkison and others, 2006; 2009; Rasmussen and others, 2009; Christensen and others, 2010). 


\section{Methods}

A groundwater monitoring plan for the Independence well field was developed based on selection criteria that included source contributions, CRAs, groundwater travel times, and current (2011) understanding of alluvial aquifer water quality. Additionally, potential threats related to surrounding land use and the geographic relation of wells to those threats were factors considered in the design.

Source contributions, CRAs, and groundwater travel times were determined from a regional groundwater flow model in conjunction with particle-tracking analysis (Kelly, 2010; Pollock, 1994). Source contributions were verified through graphical and statistical analysis of existing waterquality data (U.S. Geological Survey, 2011) and isotopic mixing equations (Kelly, 2002b). Travel times from the CRA to monitoring wells were determined, as well as travel times from monitoring wells to supply wells.

\section{Groundwater Sampling and Analysis}

Alluvial aquifer water quality was determined between 1997 through 2010 by sampling a network of 68 monitoring wells in 29 well nests located within the ZOC (fig. 1; Kelly, 2002a; 2002b; Kelly and Rydlund, 2006; Kelly, 2010). Detailed descriptions of the well network and previous samplings have been described in Kelly (1996b; 2002b; 2010). A brief description follows.

In general, monitoring well depths ranged from 6.1 meters to 36.9 meters below land surface. Well nests typically contained two wells, one deep and one shallow, each screened for a discrete depth interval. Some well nests also included an intermediate depth well screened to isolate the zone between the shallow and deep wells. Deep wells ( 28 wells) had a median depth of 22.3 meters below land surface, whereas the median depth of shallow wells ( 29 wells) was almost one-half that amount. Monitoring wells were sampled quarterly from 1997 to 2000 (Kelly, 2002b) and thereafter at intervals ranging from once per year to once every 5 years. In total, more than 700 water-quality samples were collected from these wells between 1997 through 2010 to assess groundwater quality (Kelly, 2010). For comparison purposes, during each round of monitoring well sampling, water samples also were collected from the Independence well field. The well-field water samples were a composite mixture from all supply wells pumping on the day of sampling, collected before water treatment. Water-quality data collected before 2009 have been reported in published reports (Kelly, 2002a; 2002b; Kelly and Rydlund, 2006; Kelly, 2010); these data also are available online from the USGS National Water Information System (http://waterdata.usgs.gov/mo/nwis/qwdata) as are data collected from 2009 through 2010. Selected waterquality data also are available in annual USGS data reports (U.S. Geological Survey, 2011). Samples were collected and processed in accordance with established USGS protocols for sampling preparation, selection and cleaning of equipment, collection and processing of water samples, and measurement of field parameters (U.S. Geological Survey, variously dated).

Water samples were collected and analyzed for dissolved oxygen and the physical properties $\mathrm{pH}$, specific conductance, water temperature, and turbidity, and for nutrients (nitrogen and phosphorus species), major ions and trace metals, organic microconstituents including the herbicides atrazine and alachlor, wastewater indicator compounds, and fuel compounds. The wastewater indicator compounds analyzed included compounds related to human use such as caffeine, cotinine (nicotine by-product), n,n-diethyl-meta-toluamide (DEET), sterols (such as cholesterol and coprostanol), and triclosan (antimicrobial compound frequently added to soaps and detergents). Fuel compounds analyzed included BTEX.

Monitoring well data were subdivided into categories that included relative percent of source contributions, geographic location, and groundwater travel times. Graphical displays, including piper box plots, were then used along with nonparametric statistical techniques (Helsel and Hirsch, 1992) to examine differences and similarities between categories. A geographic information system $\left(\mathrm{ESRI}^{\circ} \mathrm{ArcMap}{ }^{\circledR} 9.3\right.$, Environmental Systems Research Institute, Inc.) was used in conjunction with information about CRAs, current land-use practices, and permitted (Missouri Department of Natural Resources or U.S. Environmental Protection Agency) facilities within the ZOC to identify well sampling intervals.

\section{Quality Assurance}

Calibration details, including root mean square (RMS) error between observed and simulated hydraulic head, sensitivity analysis of model parameters, a groundwater flow budget, and limitations on the use of the calibrated groundwater model have been described in detail (Kelly, 2010). The RMS error for more than 2,500 daily water-level observations from monitoring wells was 0.44 meter, a value less than the maximum measurement errors and an indication that the calibration is acceptable (Kelly, 2010). The sensitivity analysis indicated that the model was most sensitive to well pumpage, an indication that changes in pumpage can alter groundwater travel times to wells. Thus, water quality in wells can be affected by pumpage changes. The percent discrepancy of the model between flows into versus flow out of the modeled area was -0.01 percent (Kelly, 2010).

Quality-assurance data for sample and replicate pairs of discrete water-quality sample data have been published previously (Kelly, 2010). These data indicate sampling and laboratory procedures were sufficient to prevent bias of analytical results for constituents analyzed (coefficients of determination ranged from 0.94 to 0.99 ) with the possible exception of DEET and phenol. Because of this, DEET and phenol were removed from considerations in this analysis. Other studies have determined that given the low detection limits of some organic microconstituents combined with the expected low 
environmental concentration, collection, analysis, and results interpretation for these compounds should always be done in conjunction with additional lines of evidence (Glassmeyer and others, 2005; Dickenson and others, 2011).

Quality-assurance data for triclosan by immunoassay (Shelver and others, 2007), a proposed surrogate compound and method for examining the occurrence of human pharmaceuticals and wastewater compounds, is provided in figure 5 . In summary, the triclosan by immunoassay provides a minimum reporting level of 0.02 micrograms per liter $(\mu \mathrm{g} / \mathrm{L})$, comparable to those provided by gas chromatograph/mass spectrometry methods (Shelver and others, 2007). The coefficient of determination of predicted versus measured concentrations (56 samples) was 0.991 (fig. $5 A$ ). Laboratory replicate samples $(n=25)$ and field replicate samples $(n=9)$ had coefficient of determinations greater than 0.99 (fig. 5B). Analytical comparison samples $(n=48)$ between triclosan by immunoassay and triclosan by gas chromatograph/mass spectrometry (fig. $5 \mathrm{C}$ ) indicated strong agreement between the methods (coefficient of determination, 0.84). Together these data indicate that the precision and accuracy of the triclosan by immunoassay method is capable of determining concentrations within the range of expected environmental concentrations (Wilkison and others, 2009).

\section{Groundwater Monitoring Plan}

This report presents a groundwater monitoring plan for the Missouri River alluvial aquifer in the vicinity of the Independence well field. The plan design was based upon analyses of source contributions, CRAs, mean groundwater travel times within the CRA, and potential contamination sources in conjunction with water-quality data collected from an existing monitoring well network during 1997 through 2010.

\section{Source Contributions and Contributing Recharge Areas}

Groundwater flow within the study area has been shown to be largely determined by three conjunctive factors: wellfield pumpage, Missouri River discharge, and aquifer recharge (Kelly, 2010). A change to any of these conditions potentially alters groundwater flow and, therefore, well-field source contributions. Well-field pumpage refers to supply wells within the Independence well field as well as adjacent municipal well fields (Liberty; fig. 2) and industrial wells that may substantially alter flow paths. Pumping rates can, and do, change with time, especially as population shifts occur within the study area (fig. 4). In response to an increased number of wells and increased groundwater demand, mean annual well-field pumping rates increased, on average, 15 percent per decade between 1990 and 2010 (fig. 4). The term aquifer recharge generally refers to precipitated infiltration; however, recharge rates also can be affected by conditions other than precipitation.
Missouri River discharge affects river leakage and consequently, recharge rates in the study area. In wet years, when discharge, and consequently river stage, increased, groundwater levels rose (fig. 6). During drier periods, such as 2002 through 2006, groundwater levels declined in response to decreasing river discharge. Pumping conditions also affect recharge rates by inducing cones of depression and altering groundwater flow paths.

Because of the geographic location of the Independence well field (fig. $2 A$ ) and the nature and primary direction of groundwater flow surrounding the well field (fig. $2 B$ ), the predominant source of groundwater to monitoring wells in the study area is the Missouri River (fig. 7; Kelly, 2010). Most monitoring wells received more than 90 percent of their water from the Missouri River. Conversely, only a small percent of monitoring wells were predominantly recharged by landsurface contributions within the ZOC.

Source contributions affected alluvial aquifer water quality. Because water flowing to most monitoring wells originated in the Missouri River, monitoring well water quality reflected that of the river. Water-quality data, categorized by the mean percent Missouri River contribution to the monitoring well and the location of the well in relation to the river, are shown in figures 8 and 9 .

Piper diagrams graphically illustrate the relative percent of various constituents in relation to one another (fig. 8). The diagrams consist of separate ternary plots for the principal anions and cations along with a diamond plot that integrates both. These plots allow graphical comparisons of water chemistry in time series and between groups. Linear patterns within the data indicate that temporal and spatial changes in water chemistry occur; where data clusters overlap, water chemistry is similar. Both patterns are evident (fig. 8) as would be expected in a system in which a continuum exists. This continuum includes temporal changes in water quality (data collection extended for more than a decade), spatial variations (well locations vary in relation to the Missouri River), and source variations (the percent of Missouri River water varies within each defined category). For comparison purposes, Independence supply-well and Missouri River data also are plotted on the diagrams. Supply-well values either fall within the boundaries of Missouri River values or overlap those from monitoring wells that receive, on average, more than 90 percent contributions from the Missouri River. These data indicate, and corroborate the groundwater model results, that most (greater than 90 percent) of water from supply wells originated from the Missouri River (fig. 8). The data also indicate that spatial differences occur in groundwater quality as evidenced by the slight shifts in values within groups as well as by the clustering of results from wells north of the Missouri River compared to wells south of the Missouri River (fig. 8).

Boxplots of calcium, chloride, and sodium concentrations in water from monitoring wells, Independence supply wells, and the Missouri River are shown in figure 9. As the mean percent Missouri River water contribution increased to monitoring wells, calcium concentrations declined, whereas chloride 


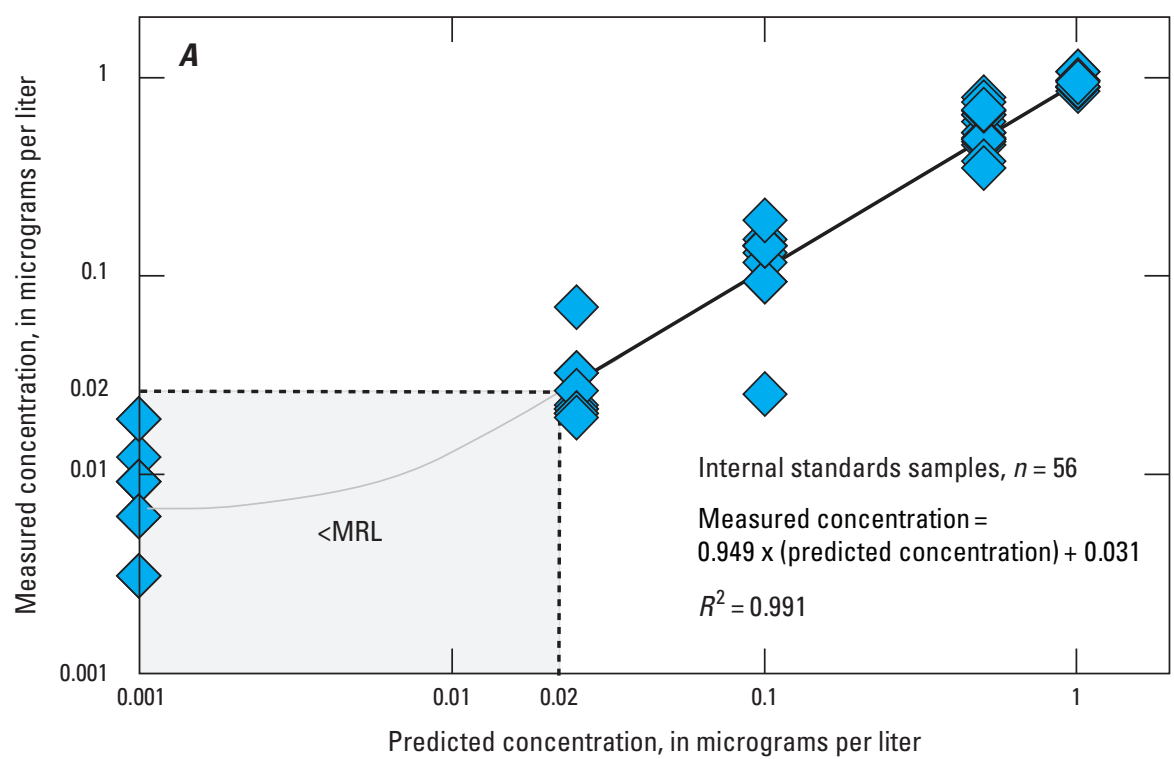

EXPLANATION

$n \quad$ Number of samples

$R^{2} \quad$ Coefficient of determination

$<M R L$ Less than Method Reporting

Level (MRL)

$<\quad$ Less than
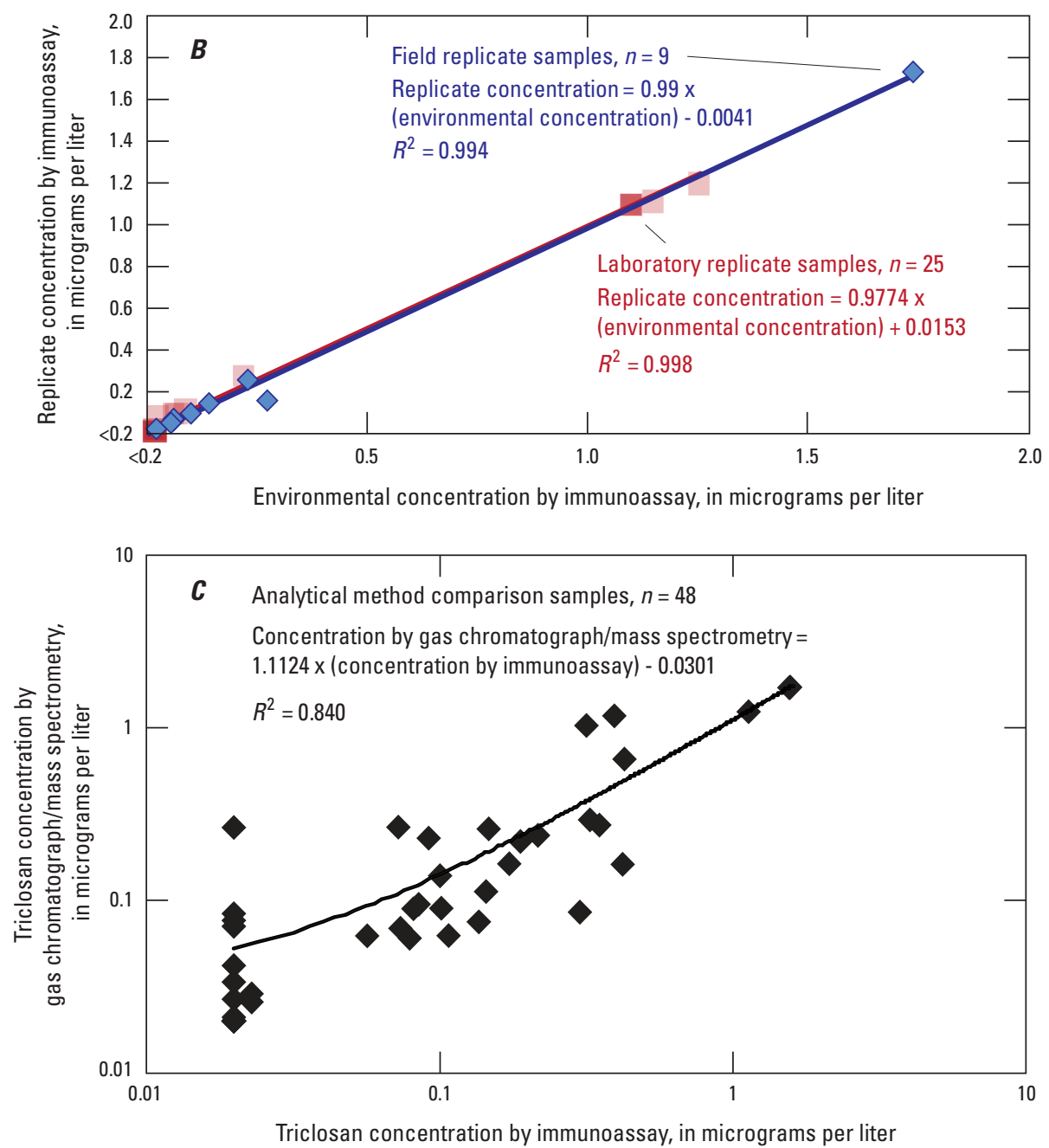

Figure 5. Triclosan quality assurrance samples using immonassay method, 2008 through 2010. A, Predicted versus measured triclosan concentrations by immunoassay; $B$, comparison of laboratory and field replicate sample concentrations; and $C$, analytical method comparison sample. 


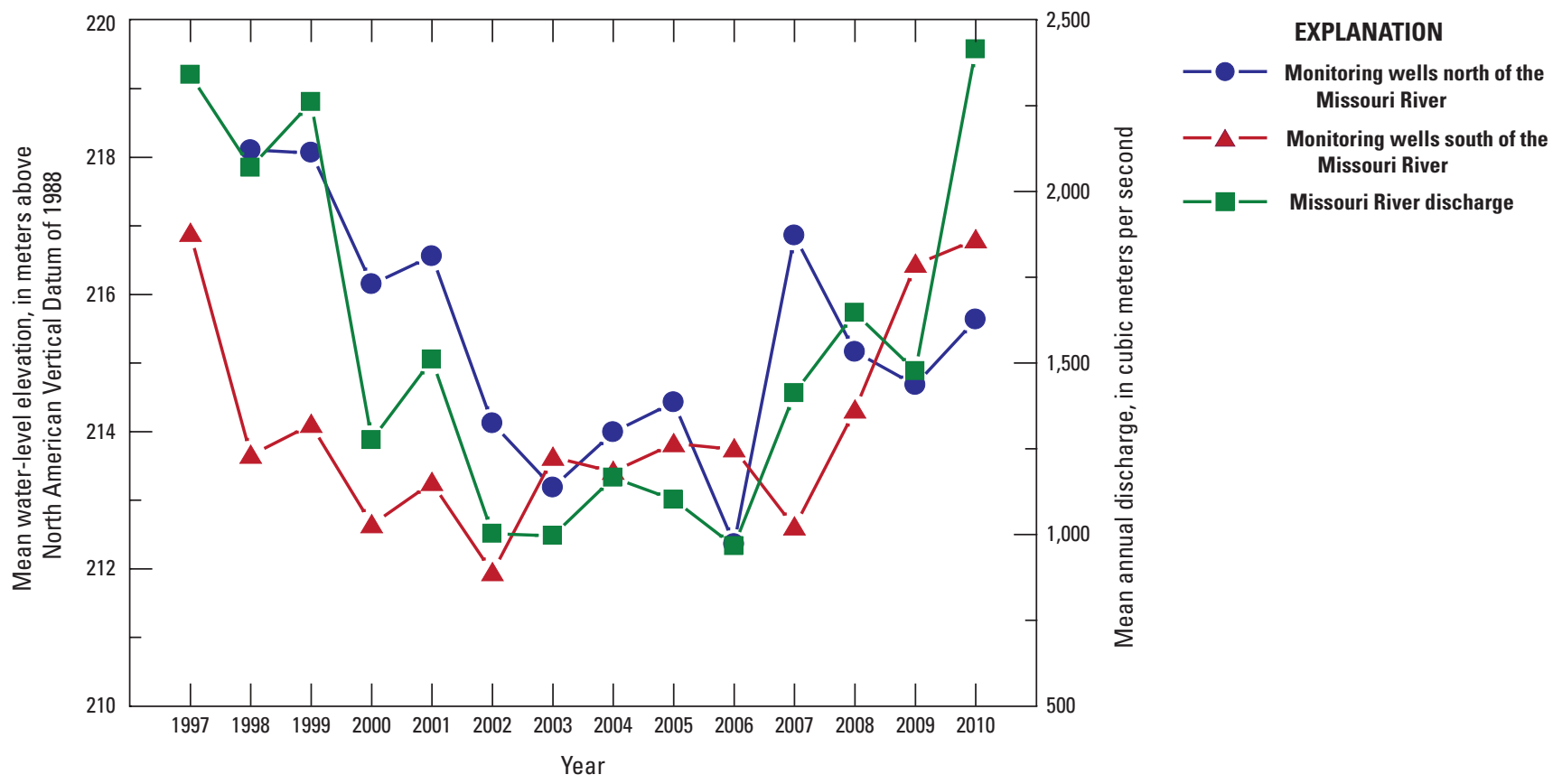

Figure 6. Mean water level in monitoring wells sampled from 1997 through 2010 and relation to mean annual Missouri River discharge.

and sodium concentrations increased (fig. 9). Median chloride concentrations in supply-well samples were nearly identical to Missouri River samples, whereas calcium and sodium concentrations plotted on a continuum between the Missouri River and monitoring wells with greater than 90 percent Missouri River water (fig. 9). These data provide another indication that Independence supply-well water originated primarily within the Missouri River and that alluvial water quality reflects, to some degree, river water quality.

However, Missouri River contributions to the underlying alluvial aquifer were constantly in flux. This is because river discharge was a combination of recent precipitation, releases from upstream reservoirs, and groundwater contributions - all of which frequently changed. As a result, the isotopic signature of Missouri River water, when compared to the meteoric water line, varied with time (fig. 10). Isotopic signatures are an expression of the ratio of the stable isotopes of hydrogen $\left({ }^{2} \mathrm{H}\right.$ [deuterium] and $\left.{ }^{1} \mathrm{H}\right)$ and oxygen $\left({ }^{18} \mathrm{O}\right.$ and $\left.{ }^{16} \mathrm{O}\right)$, compared to Vienna Standard Mean Ocean Water and expressed in delta notation $(\delta)$. The Missouri River isotopic shift (fig. 10) was likely caused by evaporation occurring in large reservoirs that subsequently reduced $\delta \mathrm{D}$ values and enriched $\delta \mathrm{O}^{18}$ values in comparison to precipitation values (Kelly and Rydlund, 2006). Water samples from monitoring wells had, on average, minimum travel times from the CRA of greater than 50 years (Kelly, 2010) plotted on the meteoric water line (green triangles; fig. 10) an indication that the primary source of this water was infiltration of precipitation.
Monitoring wells that received most of their water from the Missouri River and had relatively short travel times (yellow diamonds; fig. 10) plotted along the Missouri River sample trend line, as did the Independence supply wells. This is further indication that the primary source of water in these monitoring wells and the Independence supply wells originates from the Missouri River.

All together the isotopic data, like the piper diagrams presented earlier, indicate a mixing pattern of recent and older water within the river, monitoring wells, and supply wells.

Only five monitoring wells (20b; 22b, 22c; 24c; and 28b) had, on average, more than 90 percent of their ZOC originate at the land surface (fig. 7). All of these wells are located north of the Missouri River. Although these wells also may receive a portion of older, alluvial water they potentially provide valuable information about the threats posed by particular land uses within the ZOC.

Agriculture is the predominant land use in the study area (fig. 3), and elevated concentrations of pesticides and nutrients or both in groundwater could be indicative that agricultural land practices affect alluvial water quality. The detection frequency of two commonly used agricultural herbicides, atrazine and alachlor, for a 10-year period is shown in table 2. Monitoring wells located north of the Missouri River had a greater frequency of detection (25.4 percent) compared to those located south of the Missouri River (17.9 percent). Monitoring wells that had the least amount, on average, of land-surface recharge also had lower detection frequencies (21.5 percent). 


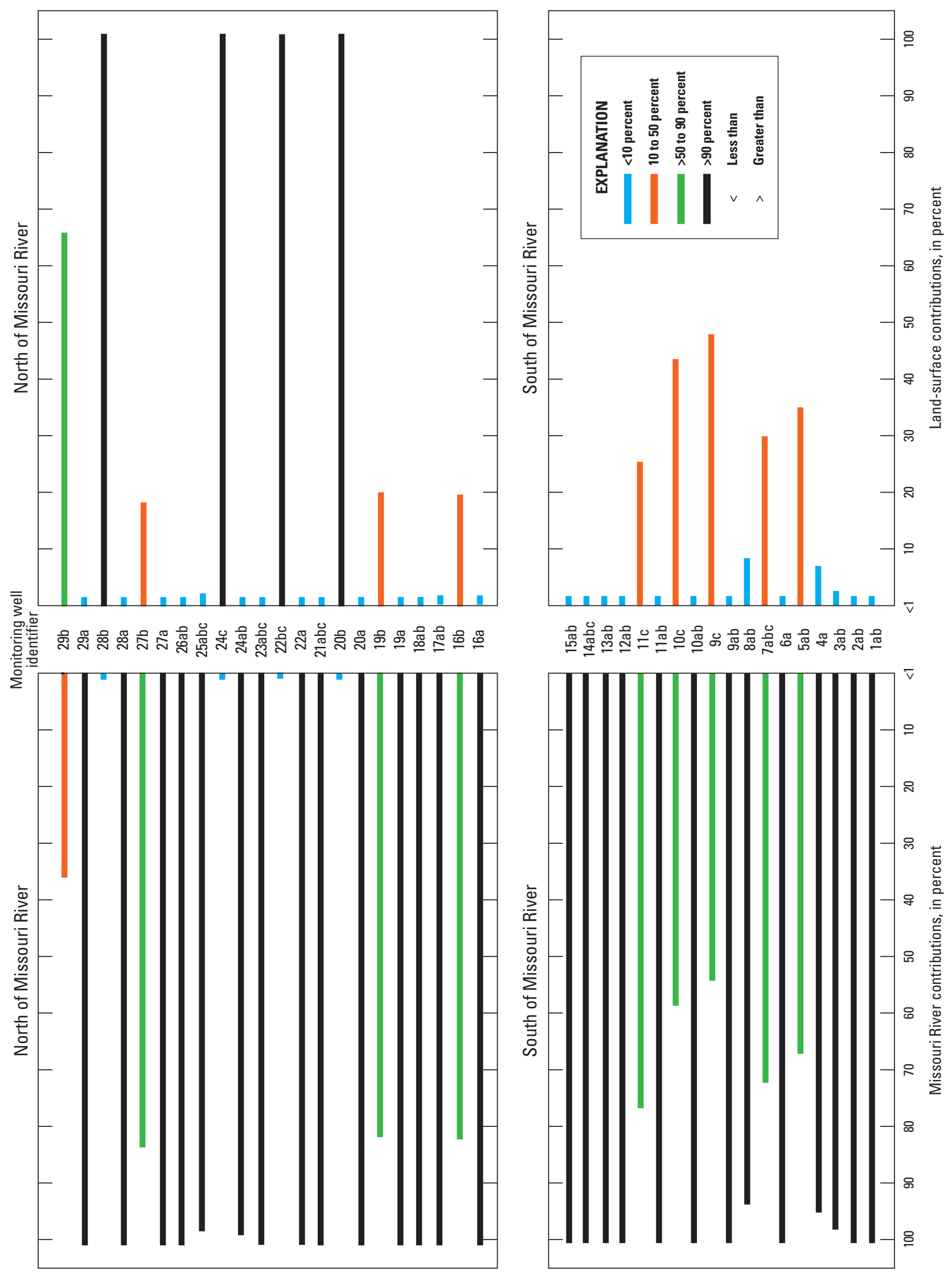

Figure 7. Mean percent Missouri River or land-surface contributions to recharge in study area monitoring wells (data from Kelly, 2010). 
$\boldsymbol{A}$

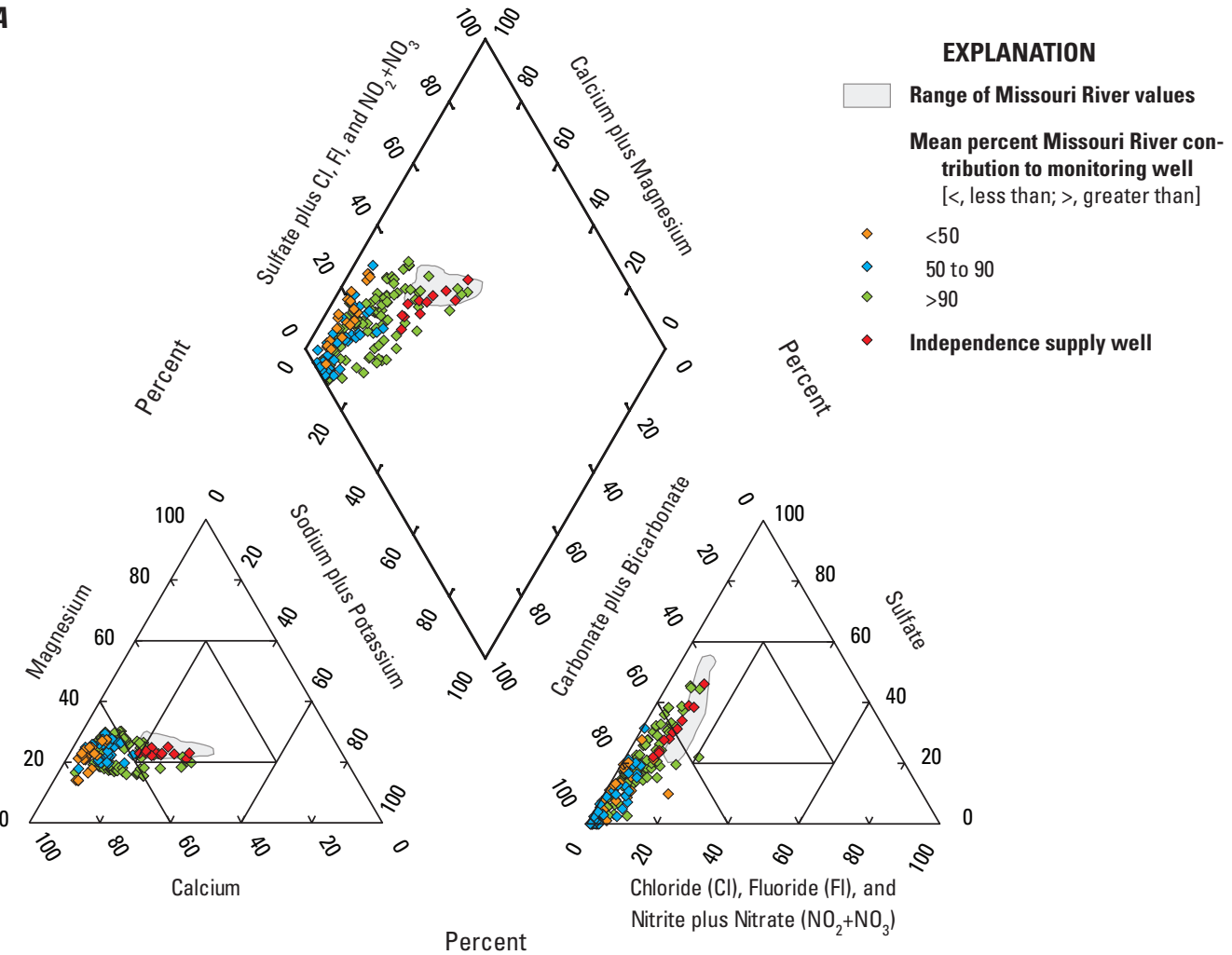

B

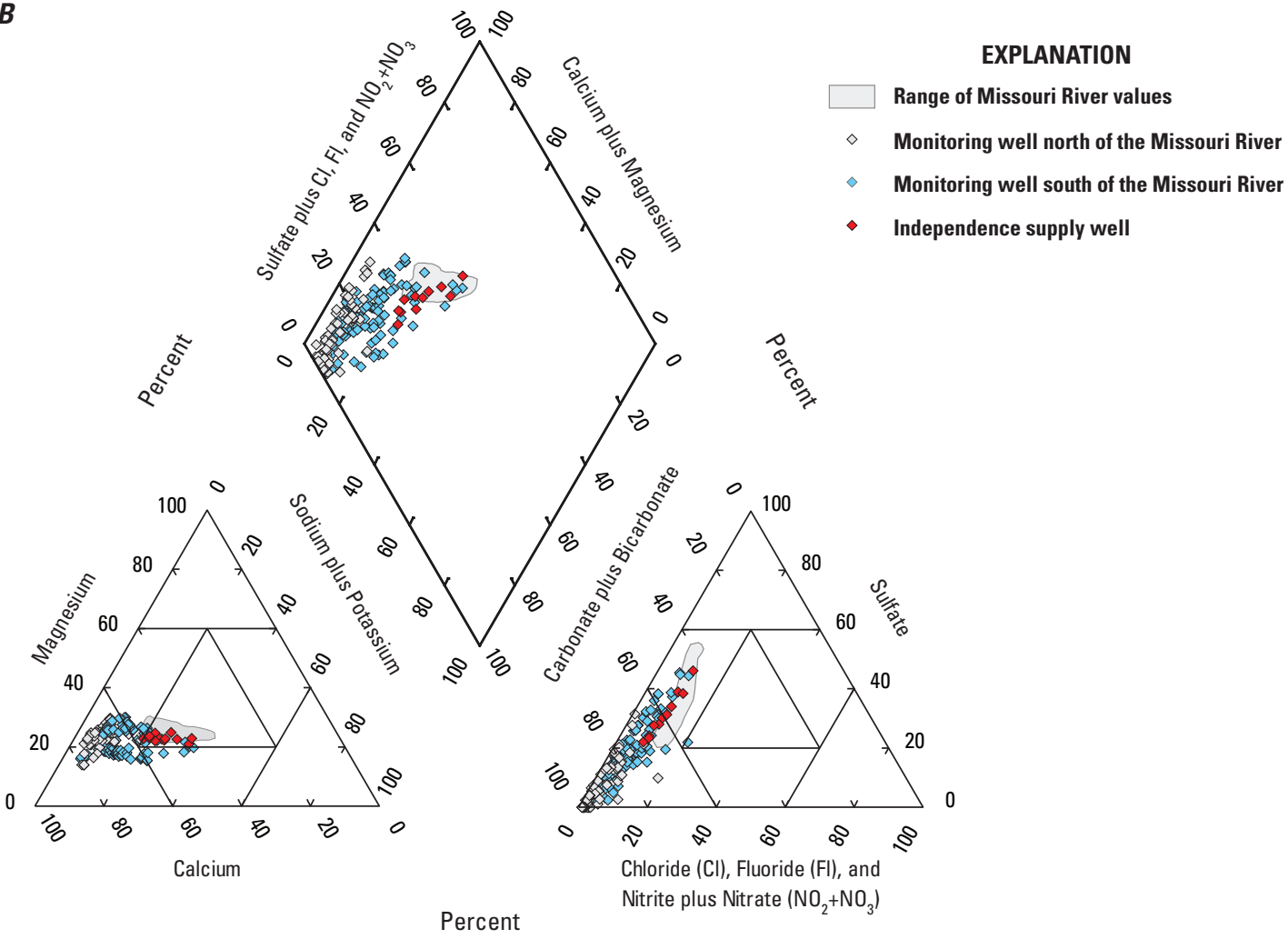

Figure 8. Piper diagram based upon $A$, mean percent Missouri River contribution to monitoring well; and $B$, geographic location. 

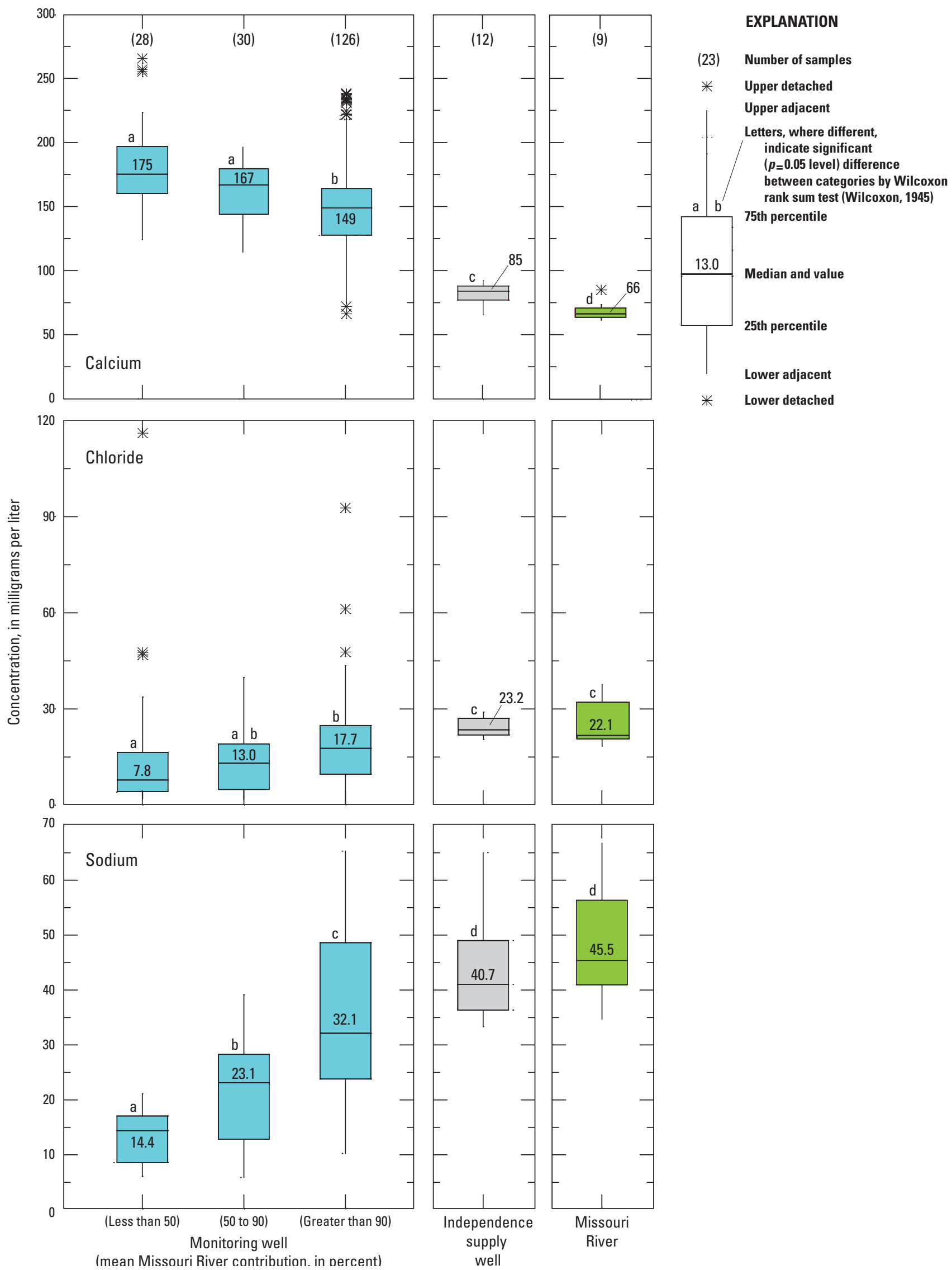

Figure 9. Calcium, chloride, and sodium concentrations in water samples collected from December, 1997 through December, 2010. 


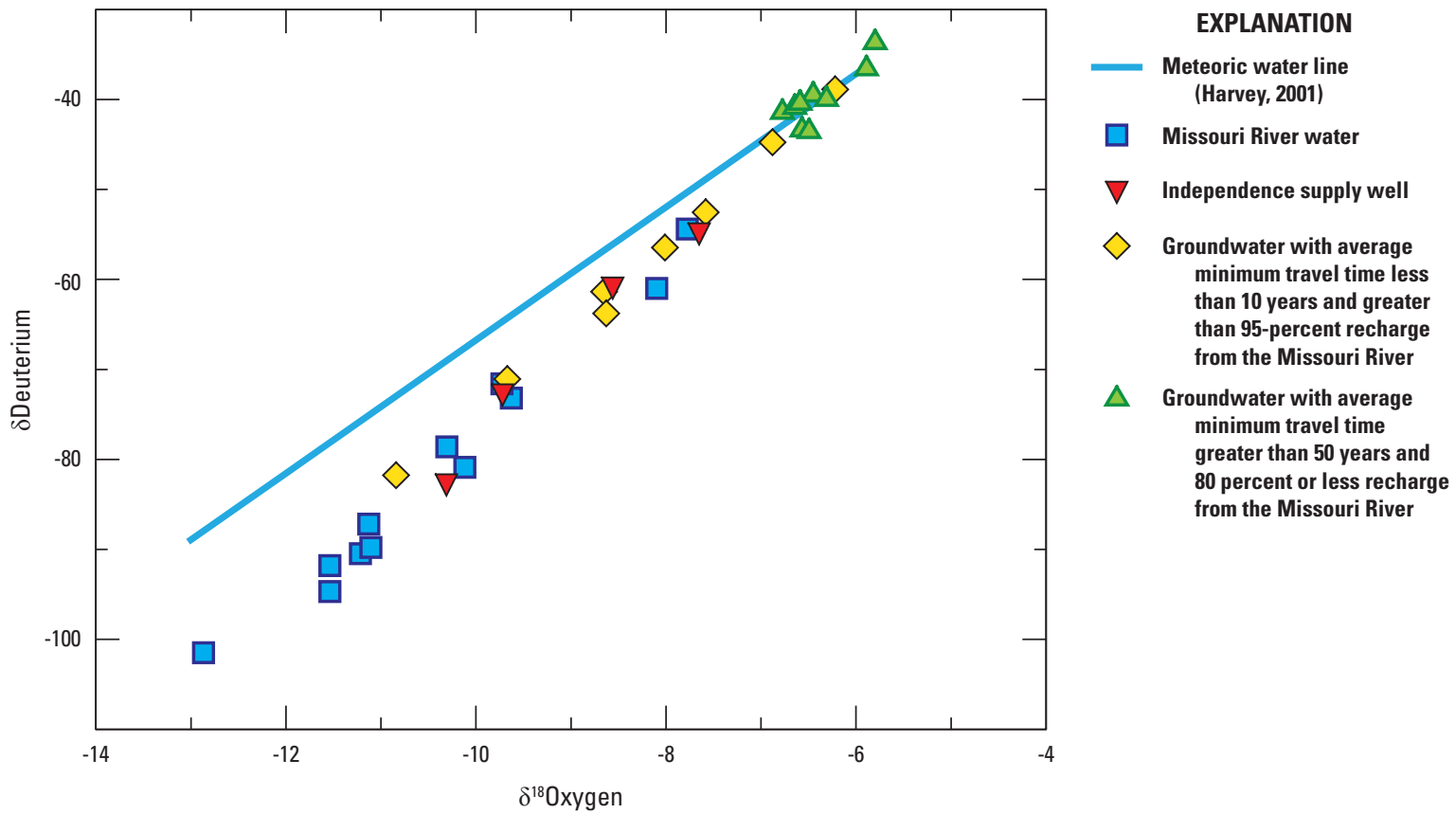

Figure 10. $\delta_{18} 0 x y g e n$ and $\delta$ deuterium values for the Missouri River, Independence supply wells, and groundwater within the Independence well field contributing recharge area (modified from Kelly, 2002b). [ $\delta$, parts per thousand with respect to Vienna Standard Mean Ocean Water]

These data are consistent with previous findings (Kelly, 2002a) where larger detection frequencies and maximum concentrations of agricultural chemicals were found in the shallowest monitoring wells. Additionally, Kelly (2002a) concluded that induced Missouri River recharge likely played a role in the distribution of agricultural chemicals (notably nutrients) within the alluvial aquifer. It should be noted that herbicide concentrations, where detected in monitoring wells, were typically near the method detection limit and several orders of magnitude below the maximum contaminant level for groundwater (Missouri Department of Natural Resources, 2009b). Additionally, riverbank filtration and biogeochemical processes frequently act to further reduce constituent concentrations (Kelly and Rylund, 2006).

Ammonia and nitrite plus nitrate concentrations in samples from the Missouri River and supply wells compared to concentrations in monitoring wells - as grouped by the mean land contribution to them - are illustrated in figure 11. Ammonia concentrations (and the percent that ammonia contributed to total nitrogen) were least in samples from the Missouri River and about three times that level (median concentration of $0.17 \mathrm{mg} / \mathrm{L}$ ) in supply-well samples. Larger median ammonia concentrations, as well as the percent that ammonia represented in terms of the total nitrogen, were observed in monitoring well samples when compared to supply well and Missouri River samples (fig. 11). Nitrite plus nitrate concentrations (and the percent that nitrite plus nitrate contributed to total nitrogen) were greatest in Missouri River samples (median concentration of $1.85 \mathrm{mg} / \mathrm{L}$ ), but only about 20 percent of that value in supply well samples (fig. 11).
Median nitrite plus nitrate concentrations in monitoring wells were nearly equivalent for land-surface contribution categories. Generally, the only appreciable concentration of nutrients in monitoring wells occurred in the form of ammonia. This is primarily caused by reducing conditions that act to convert nitrate, which primarily moves into the aquifer from the Missouri River (fig. 11) into more reduced forms. Median ammonia concentration, as well as the percent that ammonia

Table 2. Average percent detection of agricultural chemicals (atrazine and alachlor) by enzyme-linked immunosorbent assay for water samples collected between 1999 through 2009.

$[>$, greater than; $<$, less than]

\begin{tabular}{ccc}
\hline $\begin{array}{c}\text { Contributing } \\
\text { recharge area } \\
\text { originating at land } \\
\text { surface, in percent } \\
\text { (Kelly, 2010) }\end{array}$ & $\begin{array}{c}\text { Number } \\
\text { of samples }\end{array}$ & $\begin{array}{c}\text { Detection } \\
\text { frequency }\end{array}$ \\
\hline$>50$ & 45 & 26.7 \\
$10-50$ & 91 & 26.4 \\
$<10$ & 288 & 21.5 \\
\hline $\begin{array}{c}\text { Location of } \\
\text { monitoring well } \\
\text { with respect to the } \\
\text { Missouri River }\end{array}$ & $\begin{array}{c}\text { Number } \\
\text { of samples }\end{array}$ & $\begin{array}{c}\text { Detection } \\
\text { frequency }\end{array}$ \\
\hline $\begin{array}{c}\text { North } \\
\text { South }\end{array}$ & 272 & 25.4 \\
\hline
\end{tabular}




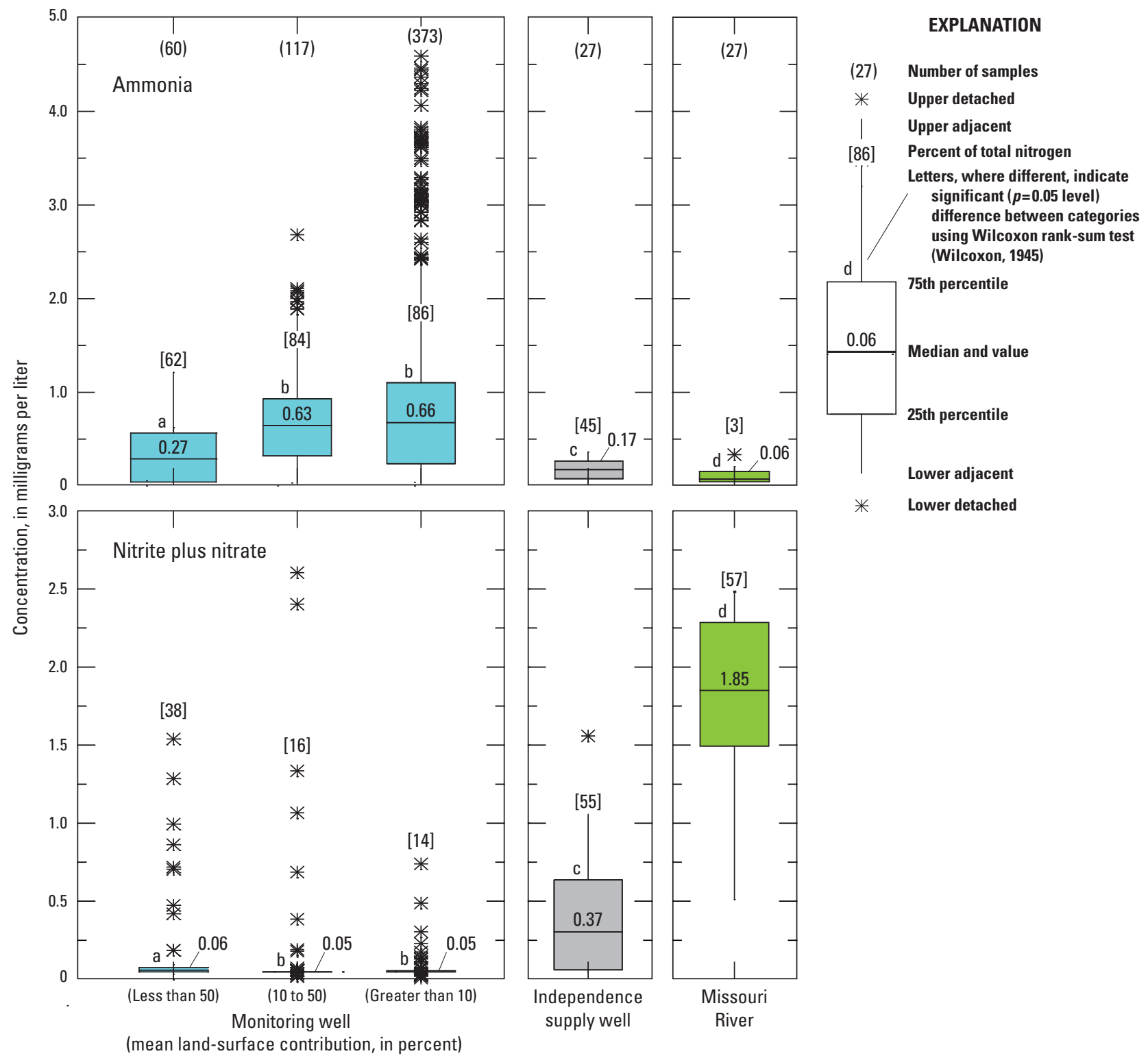

Figure 11. Ammonia, nitrite plus nitrate concentrations, and mean percent of total nitrogen in water samples collected from December, 1997 through December, 2010.

represented in terms of the total nitrogen, declined in samples as land-surface contributions increased. Riverbank filtration likely also acts to remove organic nitrogen (which generally constitutes 40 percent of the total river nutrients) as water moves from the river into the aquifer.

If land-surface nutrient contributions were substantial, and absent of transformative processes, nitrite plus nitrate concentrations would be expected to be greatest in wells with the largest percent of land-surface contributing area. However, this was not observed as there was little difference in nitrite plus nitrate concentrations between land-surface contribution categories. Concentrations were at, or near the method detection limit for each land-surface contribution category.
Median concentrations were slightly higher $(0.37 \mathrm{mg} / \mathrm{L})$ in the supply wells and approximately 5 times higher in Missouri River samples $(1.85 \mathrm{mg} / \mathrm{L})$. Total nitrogen concentrations would appear to follow a trend indicating that the largest source of nitrogen likely originates from the Missouri River. Organic nitrogen comprises a large percentage of nutrients within the river (40 percent), but not in the alluvial aquifer (0 percent). Increased median ammonia concentrations in monitoring wells when compared to supply wells and Missouri River samples (fig. 11) were likely the result of reducing conditions within the aquifer that transformed nitrate which originated from the Missouri River - then entered the aquifer-into ammonia. 


\section{Mean Groundwater Travel Times}

The CRA for the Independence well field extends approximately 10 kilometers $(\mathrm{km})$ westerly, or upgradient, and approximately $3 \mathrm{~km}$ easterly, or downgradient, from the well field (fig. 2A). Groundwater travel times, determined for steady-state groundwater flow based upon 2007 well pumpage rates, mean annual river stage, and mean annual recharge (Kelly, 2010), indicate that travel times to supply and monitoring wells where flow paths intersect the Missouri River are typically 2 years or less (fig. $2 B$ ). Within a kilometer of the well field, average groundwater travel times also were generally 2 years or less, primarily in response to steeper hydraulic gradients created by cones of depression induced by Independence and Liberty supply wells (fig. 1; fig. $2 A$ ).

The concept of groundwater travel time to, and from, monitoring wells is illustrated in figure 12. Data are further divided into two groups, wells north and south of the Missouri River. Groundwater flows from the CRA to the monitoring well and then away from the monitoring well toward the nearest supply well. Conceptually, groundwater can be thought of as moving from the left side of the diagram (the CRA) towards the center (the monitoring well) and then away from the well (toward the right) and to the nearest supply well. Maps of these flow paths are shown in the appendix. Groundwater with long travel times from the CRA to monitoring wells represents older, alluvial water when compared to groundwater with much shorter travel times. This provides a basis for comparing long-term and more recent alluvial water quality.

Wells representing each time-of-travel category are approximately equally distributed north and south of the Missouri River, although mean travel times from the CRA to wells south of the river are generally less than the travel times north of the Missouri River. As previously noted, wells with short travel times from the CRA tend to have a large component of water that originates from the Missouri River.

The relation between monitoring wells and the nearest supply well can also be described by the mean groundwater travel time (fig. 12). For example, six wells (3a,b; 16b; 27a,b; and 29b) had mean groundwater travel times from the CRA to the monitoring well of greater than 50 years combined with travel times from the monitoring well to the nearest supply well of more than 5 years (fig. 12). Conversely, 8 monitoring wells south of the Missouri River (fig. 12) and 8 wells north of the Missouri River had short travel times (average less than 5 years) from the contributing recharge area to the monitoring well as well as short travel times (average less than 2 years) from the monitoring well to the supply well. These wells provide water-quality data on the most recent groundwater that moves into supply wells, whereas the aforementioned wells (longest travel times) provides data on older alluvial water that moves into supply wells. Another way to view this is that the longer travel time group provides background data against which to compare the shorter travel time group.

The remaining monitoring wells had average travel times from the contributing recharge area to the monitoring well that ranged from 5 to 50 years. Average travel times from these monitoring wells to the nearest supply well ranged from less than a year (wells 23a, b, c) to 5.5 years (wells 8a, b; fig. 12). These wells provide data on alluvial water of intermediate age between those with the shortest travel times and those with the longest.

\section{Potential Contamination Sources and Contaminants of Concern}

Potential contamination sources to the aquifer include contaminants that enter the Missouri River and then subsequently are drawn into the alluvial aquifer include agricultural chemicals applied to the land surface and then migrate through the unsaturated zone into the alluvial aquifer, chemical spills associated with transportation arteries (including the Missouri River, rail lines, and highways) that bisect the study area, releases from permitted hazardous waste and NPDES facilities within the study area, and migration of urban point and nonpoint source pollutants into the aquifer. Given that the primary source of water to supply wells has been demonstrated to originate within the Missouri River, contaminants that enter the river are likely a principal threat to alluvial water quality.

One compounding factor is that Missouri River water quality can, and does, vary throughout the year. For example, river chloride concentrations had a strong seasonal component with the largest median concentrations occurring in the period November through February of each year (fig. 13). Although these changes may have been related to increased use of road deicers during this time frame, concentration changes also were strongly related to changes in discharge in the Missouri River (fig. 13B). As discharge decreased, chloride concentration also increased (fig. 13B). This may be because lower discharges also coincide with the period in which deicer use would have been expected to be the most prevalent or it may be the result of less dilution.

Concentrations of other common constituents in the Missouri River follow different seasonal patterns. For example, Missouri River pesticide concentrations typically peaked in late spring/early summer and then declined throughout the remainder of the year (fig.13C). Increased pesticide concentrations also were related to increased discharge in the Missouri River (fig. 13D) likely because increased river discharge and runoff conditions corresponded to pesticide application periods.

Cyclic changes in Missouri River water quality would be expected to be reflected in alluvial aquifer water quality because a close connection between the two has been demonstrated; to date, studies have not been specifically designed to define this connection. However, such patterns might be difficult to resolve because as water moves from the river into the aquifer, water-quality changes quickly become evident. Kelly and Rydlund (2006) demonstrated that riverbank filtration effectively removed most bacteria, viruses, and protozoans within 9 months of water entering the alluvial aquifer. 


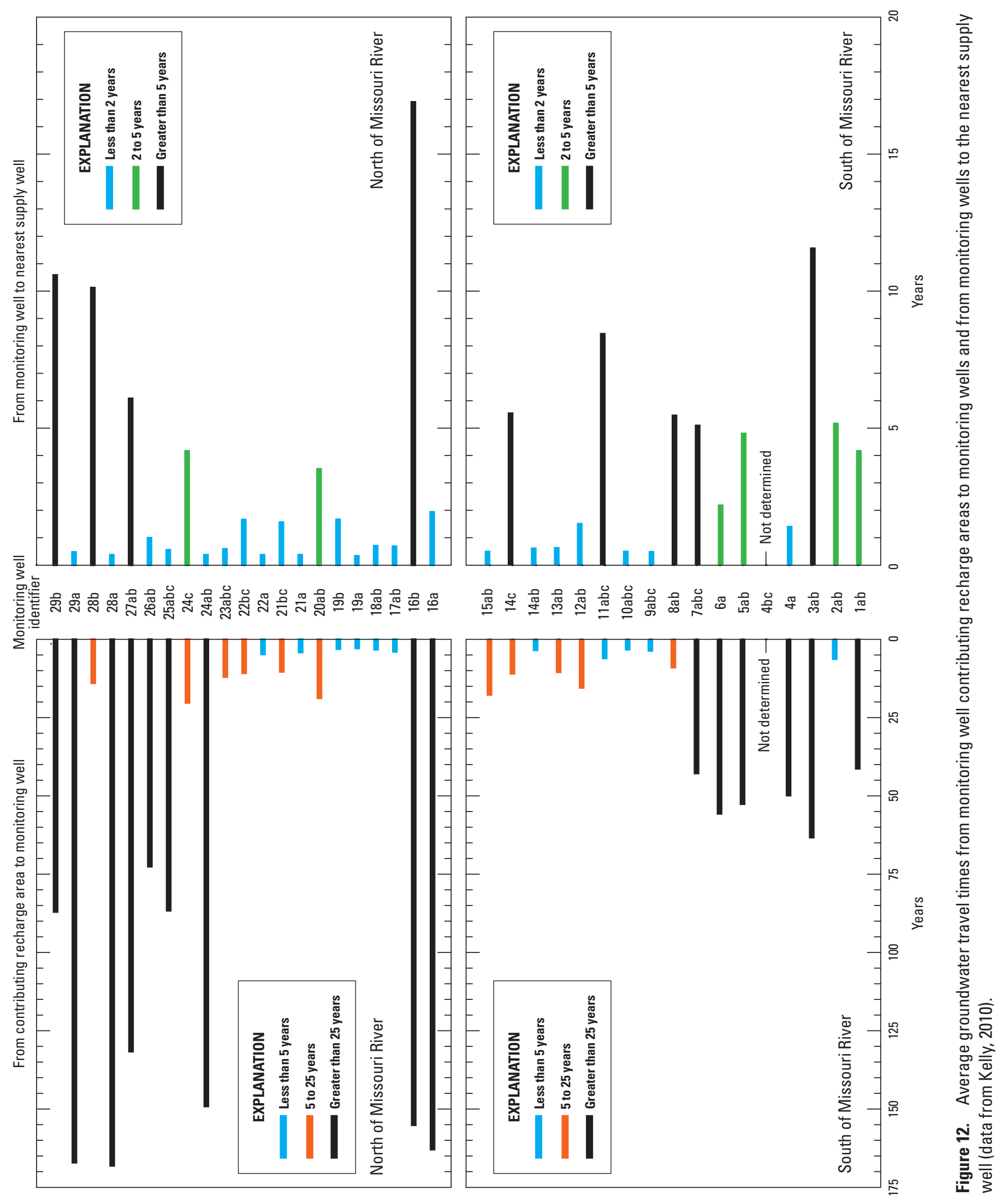



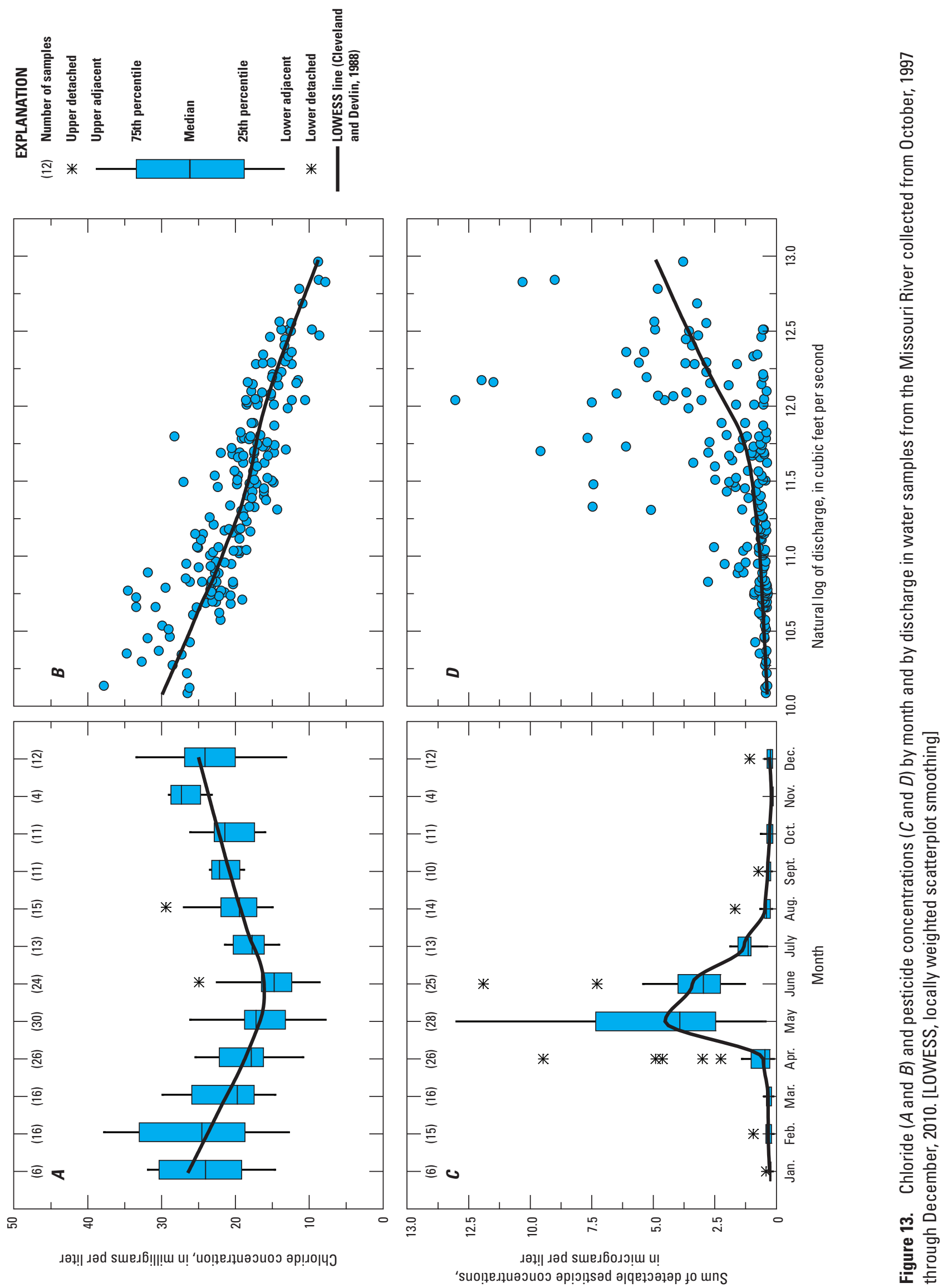
Dissolved oxygen concentrations went from near saturation in the river to near zero in the aquifer. Changes in nutrient speciation, as water moves from the river into the aquifer (previously described; fig. 11), are also an indication of waterquality changes induced by riverbank filtration. Concurrent temperature profiling of the river and nearby monitoring wells in the alluvial aquifer may provide a mechanism to better understand these changes (Vaccaro, 2011).

Tributary inputs from urban areas contribute organic contaminants to the Missouri River (Wilkison and others, 2002; 2006; Keller and others, 2003). The Blue River, approximately $10 \mathrm{~km}$ upstream from the well field, drains a large part of the Kansas City metropolitan area. Detectable concentrations of organic contaminants, including common household chemicals, detergent metabolites, the antimicrobial triclosan, pharmaceutical compounds, and polycyclic aromatic compounds (Wilkison and others, 2002; 2006; 2009; Tao and others, 2009) were frequently detected within the Blue River Basin during the period 1998 through 2010. Although concentrations were low (typically less than $1 \mu \mathrm{g} / \mathrm{L}$ ), significant loadings to the lower Blue River occurred in any given year (Wilkison and others, 2009). Triclosan has been demonstrated to be an especially ubiquitous environmental contaminant (Halden and Paull, 2005; Kumar and others, 2010). Additionally, Echols and others (2008) reported the largest concentrations of persistent organic pollutants in the $500-\mathrm{km}$ reach of the Lower Missouri River occurred at the mouth of the Blue River.

Selected monitoring wells in the study area have been sampled for many of these organic constituents (Kelly and Rydlund, 2006); however, detections have been few, and at low levels. Data on these compounds in the Missouri River are sparse. However, it is likely that Missouri River discharge and aquifer mixing would act to further dilute tributary concentrations. Additionally, once these compounds entered the alluvial aquifer, processes such as riverbank filtration, sorption, and oxidation and reduction reactions would be expected to limit groundwater transport and reduce concentrations (Verstraeten and others, 2003; Carrara and others, 2008).

The predominant land use within the ZOC is agricultural. One of the primary concerns related to agricultural practices is its effect on nutrient levels in surface and groundwater. Despite efforts to reduce nitrate levels in the Missouri and Mississippi Rivers, levels have continued to increase throughout the last two decades (Sprague and others, 2011). This is of particular concern because of the close connection between the river and the alluvial aquifer (fig. 6) and the relatively large percentage of Missouri River water that is typically directed into supply wells (figs. 7-9). Although there can be other sources of nutrients, including atmospheric deposition, point-source discharges (especially from wastewater treatment facilities), and urban nonpoint source runoff, agricultural activities are still a source of concern within the study area.

\section{Sampling Strategy}

A groundwater monitoring plan (tables 3 and 4) for the Missouri River alluvial aquifer in the vicinity of the Independence well field was developed considering factors known to affect alluvial water quality. These factors included groundwater source contributions, contributing recharge areas, groundwater travel time, well-field pumpage, Missouri River discharge, land-use practices within the CRA, and potential contamination sources.

Well sampling frequency (table 3) was based on the need to characterize the water quality from specific source areas, provide short- and long-term assessment of aquifer waterquality, to account for the inherent variability of source waters, and to provide sufficient lead time to address problems should contamination issues arise. The plan provides for an equal number of wells north and south of the Missouri River to be sampled in any given year (table 3 ).

Five monitoring wells (1b, 2b, 18a, 19a, 20a), whose recharge originated almost exclusively from the Missouri River and that had short mean groundwater travel times (from the CRA to the monitoring well, as well as from the monitoring well to the supply well; fig. 12), were chosen to be sampled annually (tables 3 and 4). The water quality of such wells would be expected to have greater variability than wells with longer travel times especially in light of the fact that wells with short travel times predominately sample Missouri River water. Additionally, five monitoring wells $(9 \mathrm{c}, 10 \mathrm{c}, 11 \mathrm{c}$, 19b, 27b) with short mean travel times from the CRA (fig.12) and source waters that predominately originated from the land surface also were chosen to be sampled once per year (tables 3 and 4). Monitoring wells with the shortest groundwater travel times within the contributing recharge area provide an estimate of the maximum potential lead time available for remedial action in the event of aquifer contamination.

The remaining monitoring wells, those with varying travel times and intermediate mixtures of river and land source contributions, were chosen to be sampled less frequently (at 2-, 3-, or 4-year intervals). The contributing recharge areas for many of these wells overlap (appendix); therefore, in any given year, some wells sample similar groundwater. The reduced sample interval for these groups of wells still provides data from similar contributing areas (table 3; appendix, fig. 1) each year, yet minimizes sampling redundancy.

Even in the absence of major changes or inputs to the system, slight groundwater quality variations occur within wells. Previously discussed factors, such as well pumpage, river levels, and temporal changes, can factor into these variations. Of these, well pumpage likely has the largest effect (Kelly, 2010). For example, as population growth increased in the region (fig. 4), Independence added supply wells and increased well-field pumpage in the period between 1990 and 2000 (primarily in areas north of the Missouri River) to respond to growing water needs. Time-series plots of specific conductance values (fig. 14) indicated that it took several years 
Table 3. Groundwater sampling frequency for the Independence well field.

[Color shading, where the same, indicates overlapping contributing recharge area, consistent travel times to and from monitoring wells, or similar primary sources of water to the monitoring well; blank when not sampled; --, contributing recharge area or groundwater travel times not currently defined]

\begin{tabular}{|c|c|c|c|c|c|c|c|c|c|c|c|c|}
\hline $\begin{array}{c}\text { Monitoring well } \\
\text { identifier }\end{array}$ & Year 1 & Year 2 & Year 3 & Year 4 & Year 5 & Year 6 & Year 7 & Year 8 & Year 9 & Year 10 & Year 11 & Year 12 \\
\hline $1 \mathrm{a}$ & $\mathrm{X}$ & & $\mathrm{X}$ & & $\mathrm{X}$ & & $\mathrm{X}$ & & $\mathrm{X}$ & & $\mathrm{X}$ & \\
\hline $1 \mathrm{~b}$ & $\mathrm{X}$ & $\mathrm{X}$ & $\mathrm{X}$ & $\mathrm{X}$ & $\mathrm{X}$ & $\mathrm{X}$ & $\mathrm{X}$ & $\mathrm{X}$ & $\mathrm{X}$ & $X$ & $\mathrm{X}$ & $\mathrm{X}$ \\
\hline $2 a$ & & $\mathrm{X}$ & & $\mathrm{X}$ & & $\mathrm{X}$ & & $\mathrm{X}$ & & $\mathrm{X}$ & & $\mathrm{X}$ \\
\hline $2 b$ & $\mathrm{X}$ & $\mathrm{X}$ & $\mathrm{X}$ & $X$ & $\mathrm{X}$ & $\mathrm{X}$ & $\mathrm{X}$ & $\mathrm{X}$ & $\mathrm{X}$ & $X$ & $\mathrm{X}$ & $\mathrm{X}$ \\
\hline $3 a$ & -- & -- & -- & -- & -- & -- & -- & -- & -- & -- & -- & -- \\
\hline $3 b$ & -- & -- & -- & -- & -- & -- & -- & -- & -- & -- & -- & -- \\
\hline $4 a$ & -- & -- & -- & -- & -- & -- & -- & -- & -- & -- & -- & -- \\
\hline $4 \mathrm{~b}$ & -- & -- & -- & -- & -- & -- & -- & -- & -- & -- & -- & -- \\
\hline $4 \mathrm{c}$ & -- & -- & -- & -- & -- & -- & -- & -- & -- & -- & -- & -- \\
\hline $5 \mathrm{a}$ & & $\mathrm{X}$ & & $\mathrm{X}$ & & $\mathrm{X}$ & & $\mathrm{X}$ & & $\mathrm{X}$ & & $\mathrm{X}$ \\
\hline $5 b$ & $\mathrm{X}$ & & $\mathrm{X}$ & & $\mathrm{X}$ & & $\mathrm{X}$ & & $\mathrm{X}$ & & $\mathrm{X}$ & \\
\hline $6 a$ & & & $\mathrm{X}$ & & & $\mathrm{X}$ & & & $\mathrm{X}$ & & & $\mathrm{X}$ \\
\hline $7 a$ & & $\mathrm{X}$ & & & & $\mathrm{X}$ & & & & $\mathrm{X}$ & & \\
\hline $7 b$ & $\mathrm{X}$ & & $\mathrm{X}$ & & $X$ & & $\mathrm{X}$ & & $\mathrm{X}$ & & $\mathrm{X}$ & \\
\hline $7 \mathrm{c}$ & & & & $\mathrm{X}$ & & & & $\mathrm{X}$ & & & & $\mathrm{X}$ \\
\hline $8 a$ & $\mathrm{X}$ & & & & $\mathrm{X}$ & & & & $\mathrm{X}$ & & & \\
\hline $8 b$ & & $\mathrm{X}$ & & & & $\mathrm{X}$ & & & & $X$ & & \\
\hline $9 a$ & & & & $\mathrm{X}$ & & & & $\mathrm{X}$ & & & & $\mathrm{X}$ \\
\hline $9 \mathrm{~b}$ & $\mathrm{X}$ & & & & $\mathrm{X}$ & & & & $\mathrm{X}$ & & & \\
\hline $9 \mathrm{c}$ & $\mathrm{X}$ & $\mathrm{X}$ & $\mathrm{X}$ & $\mathrm{X}$ & $\mathrm{X}$ & $\mathrm{X}$ & $\mathrm{X}$ & $\mathrm{X}$ & $\mathrm{X}$ & $X$ & $\mathrm{X}$ & $\mathrm{X}$ \\
\hline $10 \mathrm{a}$ & & & $\mathrm{X}$ & & & & $\mathrm{X}$ & & & & $\mathrm{X}$ & \\
\hline $10 \mathrm{~b}$ & & $\mathrm{X}$ & & & & $\mathrm{X}$ & & & & $X$ & & \\
\hline $10 \mathrm{c}$ & $\mathrm{X}$ & $\mathrm{X}$ & $\mathrm{X}$ & $\mathrm{X}$ & $X$ & $\mathrm{X}$ & $\mathrm{X}$ & $\mathrm{X}$ & $\mathrm{X}$ & $X$ & $X$ & $\mathrm{X}$ \\
\hline $11 \mathrm{a}$ & & & $\mathrm{X}$ & & & & $\mathrm{X}$ & & & & $\mathrm{X}$ & \\
\hline $11 \mathrm{~b}$ & & & & $X$ & & & & $\mathrm{X}$ & & & & $\mathrm{X}$ \\
\hline $11 \mathrm{c}$ & $\mathrm{X}$ & $\mathrm{X}$ & $\mathrm{X}$ & $\mathrm{X}$ & $\mathrm{X}$ & $\mathrm{X}$ & $\mathrm{X}$ & $\mathrm{X}$ & $\mathrm{X}$ & $\mathrm{X}$ & $\mathrm{X}$ & $\mathrm{X}$ \\
\hline $12 a$ & $\mathrm{X}$ & & & $\mathrm{X}$ & & & $\mathrm{X}$ & & & $X$ & & \\
\hline $12 b$ & & $\mathrm{X}$ & & & $\mathrm{X}$ & & & $\mathrm{X}$ & & & $\mathrm{X}$ & \\
\hline $13 a$ & $\mathrm{X}$ & & & $\mathrm{X}$ & & & $\mathrm{X}$ & & & $X$ & & \\
\hline $13 b$ & & $\mathrm{X}$ & & & $\mathrm{X}$ & & & $\mathrm{X}$ & & & $\mathrm{X}$ & \\
\hline $14 \mathrm{a}$ & $\mathrm{X}$ & & & & $\mathrm{X}$ & & & & $X$ & & & \\
\hline $14 \mathrm{~b}$ & & $\mathrm{X}$ & & & & $\mathrm{X}$ & & & & $\mathrm{X}$ & & \\
\hline $14 \mathrm{c}$ & & & $\mathrm{X}$ & & & & $\mathrm{X}$ & & & & $\mathrm{X}$ & \\
\hline $15 \mathrm{a}$ & & & & $\mathrm{X}$ & & & & $\mathrm{X}$ & & & & $\mathrm{X}$ \\
\hline $15 b$ & & & $X$ & & & $X$ & & & $X$ & & & $X$ \\
\hline $\begin{array}{l}\text { Independence } \\
\text { Well Field }\end{array}$ & $\mathrm{X}$ & $\mathrm{X}$ & X & $X$ & $X$ & $\mathrm{X}$ & $\mathrm{X}$ & $\mathrm{X}$ & $X$ & $X$ & $\mathrm{X}$ & $\mathrm{X}$ \\
\hline $\begin{array}{l}\text { Number of wells } \\
\text { south of the } \\
\text { Missouri River }\end{array}$ & 14 & 14 & 14 & 14 & 14 & 14 & 14 & 14 & 14 & 14 & 14 & 14 \\
\hline
\end{tabular}


Table 3. Groundwater sampling frequency for the Independence well field._-Continued

[Color shading, where the same, indicates overlapping contributing recharge area, consistent travel times to and from monitoring wells, or similar primary sources of water to the monitoring well; blank when not sampled; --, contributing recharge area or groundwater travel times not currently defined]

\begin{tabular}{|c|c|c|c|c|c|c|c|c|c|c|c|c|}
\hline $\begin{array}{l}\text { Monitoring well } \\
\text { identifier }\end{array}$ & Year 1 & Year 2 & Year 3 & Year 4 & Year 5 & Year 6 & Year 7 & Year 8 & Year 9 & Year 10 & Year 11 & Year 12 \\
\hline $16 \mathrm{a}$ & & $\mathrm{X}$ & & $\mathrm{X}$ & & $\mathrm{X}$ & & $\mathrm{X}$ & & $\mathrm{X}$ & & $\mathrm{X}$ \\
\hline $16 \mathrm{~b}$ & $\mathrm{X}$ & & $\mathrm{X}$ & & $\mathrm{X}$ & & $\mathrm{X}$ & & $\mathrm{X}$ & & $\mathrm{X}$ & \\
\hline $17 \mathrm{a}$ & $\mathrm{X}$ & & & & $\mathrm{X}$ & & & & $\mathrm{X}$ & & & \\
\hline $17 \mathrm{~b}$ & & $\mathrm{X}$ & & & & $\mathrm{X}$ & & & & $\mathrm{X}$ & & \\
\hline $18 \mathrm{a}$ & $\mathrm{X}$ & $\mathrm{X}$ & $\mathrm{X}$ & $\mathrm{X}$ & $\mathrm{X}$ & $\mathrm{X}$ & $\mathrm{X}$ & $\mathrm{X}$ & $\mathrm{X}$ & $\mathrm{X}$ & $\mathrm{X}$ & $\mathrm{X}$ \\
\hline $18 \mathrm{~b}$ & & $\mathrm{X}$ & & & & $\mathrm{X}$ & & & & $\mathrm{X}$ & & \\
\hline $19 \mathrm{a}$ & $\mathrm{X}$ & $\mathrm{X}$ & $\mathrm{X}$ & $\mathrm{X}$ & $\mathrm{X}$ & $\mathrm{X}$ & $\mathrm{X}$ & $\mathrm{X}$ & $\mathrm{X}$ & $\mathrm{X}$ & $\mathrm{X}$ & $\mathrm{X}$ \\
\hline $19 \mathrm{~b}$ & $\mathrm{X}$ & $\mathrm{X}$ & $\mathrm{X}$ & $\mathrm{X}$ & $X$ & $X$ & $\mathrm{X}$ & $\mathrm{X}$ & $\mathrm{X}$ & $\mathrm{X}$ & $\mathrm{X}$ & $X$ \\
\hline $20 \mathrm{a}$ & $\mathrm{X}$ & $\mathrm{X}$ & $\mathrm{X}$ & $\mathrm{X}$ & $\mathrm{X}$ & $\mathrm{X}$ & $\mathrm{X}$ & $\mathrm{X}$ & $\mathrm{X}$ & $\mathrm{X}$ & $\mathrm{X}$ & $X$ \\
\hline $20 \mathrm{~b}$ & $\mathrm{X}$ & & $\mathrm{X}$ & & $\mathrm{X}$ & & $\mathrm{X}$ & & $\mathrm{X}$ & & $\mathrm{X}$ & \\
\hline $21 \mathrm{a}$ & $\mathrm{X}$ & & & & $\mathrm{X}$ & & & & $\mathrm{X}$ & & & \\
\hline $21 b$ & & & $\mathrm{X}$ & & & & $\mathrm{X}$ & & & & $\mathrm{X}$ & \\
\hline $21 \mathrm{c}$ & & & $\mathrm{X}$ & & & & $\mathrm{X}$ & & & & $\mathrm{X}$ & \\
\hline $22 \mathrm{a}$ & $\mathrm{X}$ & & $\mathrm{X}$ & & $\mathrm{X}$ & & $\mathrm{X}$ & & $\mathrm{X}$ & & $X$ & \\
\hline $22 b$ & $\mathrm{X}$ & & $\mathrm{X}$ & & $\mathrm{X}$ & & $\mathrm{X}$ & & $\mathrm{X}$ & & $\mathrm{X}$ & \\
\hline $22 c$ & & $\mathrm{X}$ & & $\mathrm{X}$ & & $\mathrm{X}$ & & $\mathrm{X}$ & & $\mathrm{X}$ & & $\mathrm{X}$ \\
\hline $23 a$ & & $\mathrm{X}$ & & $\mathrm{X}$ & & X & & $\mathrm{X}$ & & $\mathrm{X}$ & & $X$ \\
\hline $23 b$ & & & & $\mathrm{X}$ & & & & $\mathrm{X}$ & & & & $\mathrm{X}$ \\
\hline $23 \mathrm{c}$ & & & & $\mathrm{X}$ & & & & $X$ & & & & $X$ \\
\hline $24 \mathrm{a}$ & & $\mathrm{X}$ & & & & $\mathrm{X}$ & & & & $X$ & & \\
\hline $24 b$ & $\mathrm{X}$ & & & & $\mathrm{X}$ & & & & $\mathrm{X}$ & & & \\
\hline $24 c$ & & $X$ & & X & & X & & $X$ & & X & & $\mathrm{X}$ \\
\hline $25 \mathrm{a}$ & & & $\mathrm{X}$ & & & & $\mathrm{X}$ & & & & $\mathrm{X}$ & \\
\hline $25 b$ & & & & $\mathrm{X}$ & & & & $X$ & & & & $\mathrm{X}$ \\
\hline $25 \mathrm{c}$ & & & $\mathrm{X}$ & & & & $\mathrm{X}$ & & & & $\mathrm{X}$ & \\
\hline $26 \mathrm{a}$ & & $\mathrm{X}$ & & & & X & & & & X & & \\
\hline $26 b$ & $\mathrm{X}$ & & & & $\mathrm{X}$ & & & & $\mathrm{X}$ & & & \\
\hline $27 \mathrm{a}$ & & & & $\mathrm{X}$ & & & & $\mathrm{X}$ & & & & $\mathrm{X}$ \\
\hline $27 \mathrm{~b}$ & $\mathrm{X}$ & $\mathrm{X}$ & $\mathrm{X}$ & $\mathrm{X}$ & $\mathrm{X}$ & $\mathrm{X}$ & $\mathrm{X}$ & $\mathrm{X}$ & $\mathrm{X}$ & $\mathrm{X}$ & $\mathrm{X}$ & $\mathrm{X}$ \\
\hline $28 \mathrm{a}$ & $\mathrm{X}$ & & & & $\mathrm{X}$ & & & & $\mathrm{X}$ & & & \\
\hline $28 \mathrm{~b}$ & & $X$ & & & & $X$ & & & & $X$ & & \\
\hline $29 a$ & & & $\mathrm{X}$ & & & & $\mathrm{X}$ & & & & $X$ & \\
\hline $29 b$ & & & & $\mathrm{X}$ & & & & $X$ & & & & $X$ \\
\hline $\begin{array}{l}\text { Number of wells } \\
\text { north of the } \\
\text { Missouri River }\end{array}$ & 14 & 14 & 14 & 14 & 14 & 14 & 14 & 14 & 14 & 14 & 14 & 14 \\
\hline Total wells & 28 & 28 & 28 & 28 & 28 & 28 & 28 & 28 & 28 & 28 & 28 & 28 \\
\hline
\end{tabular}


Table 4. Associated field and laboratory analysis for monitoring wells and sampling reccurrence interval (in years).

$[--$, not sampled or not applicable $]$

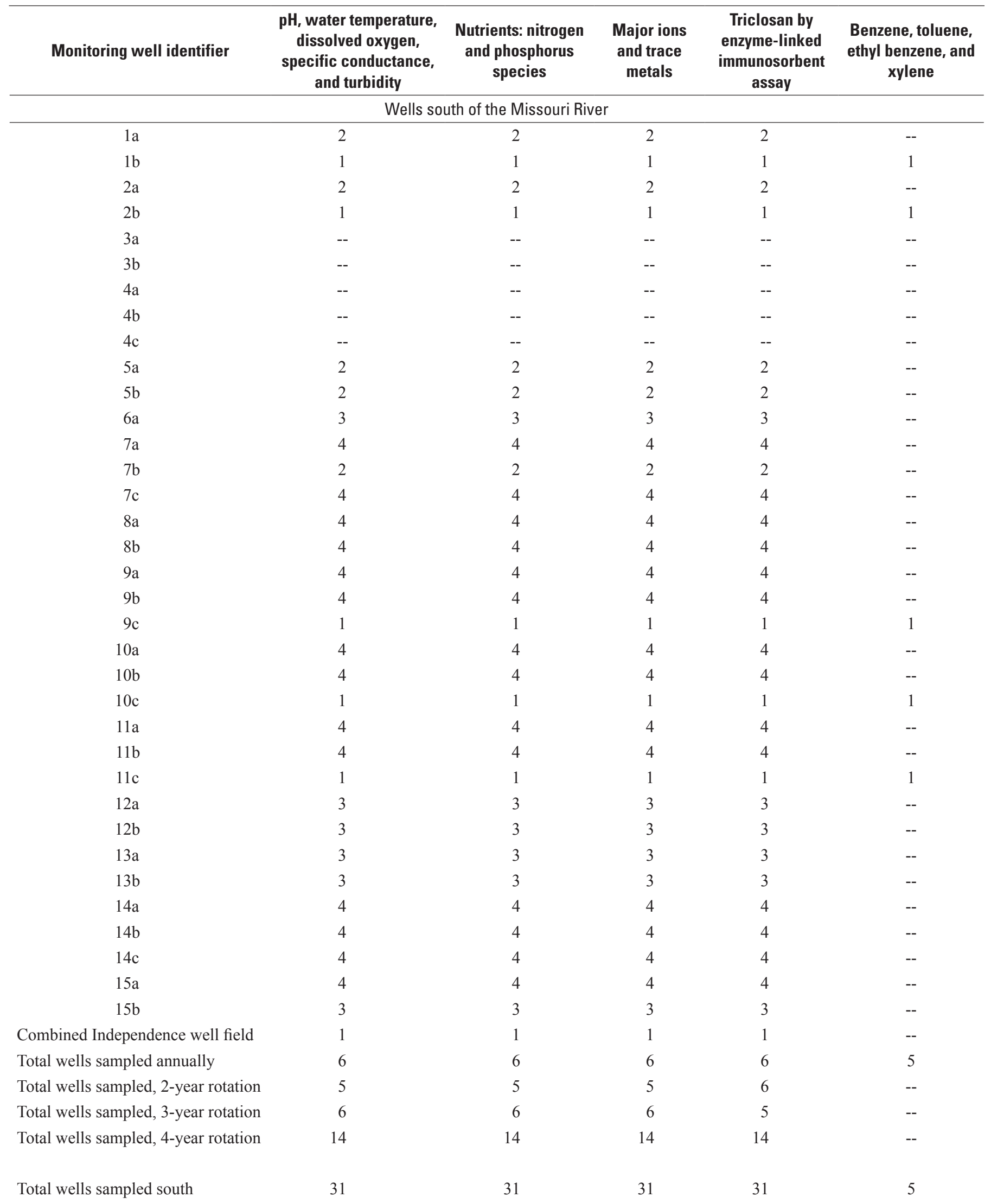




\section{Groundwater Monitoring Plan for the Missouri River Alluvial Aquifer in the Vicinity of Independence, Missouri}

Table 4. Associated field and laboratory analysis for monitoring wells and sampling reccurrence interval (in years).—Continued [--, not sampled or not applicable]

\begin{tabular}{|c|c|c|c|c|c|}
\hline Monitoring well identifier & $\begin{array}{c}\text { pH, water temperature, } \\
\text { dissolved oxygen, } \\
\text { specific conductance, } \\
\text { and turbidity }\end{array}$ & $\begin{array}{l}\text { Nutrients: nitrogen } \\
\text { and phosphorus } \\
\text { species }\end{array}$ & $\begin{array}{c}\text { Major ions } \\
\text { and trace } \\
\text { metals }\end{array}$ & $\begin{array}{c}\text { Triclosan by } \\
\text { enzyme-linked } \\
\text { immunosorbent } \\
\text { assay }\end{array}$ & $\begin{array}{c}\text { Benzene, toluene, } \\
\text { ethyl benzene, and } \\
\text { xylene }\end{array}$ \\
\hline \multicolumn{6}{|c|}{ Wells north of the Missouri River } \\
\hline $16 \mathrm{a}$ & 2 & 2 & 2 & 2 & -- \\
\hline $16 \mathrm{~b}$ & 4 & 4 & 4 & 4 & -- \\
\hline $17 \mathrm{a}$ & 2 & 2 & 2 & 2 & -- \\
\hline $17 \mathrm{~b}$ & 4 & 4 & 4 & 4 & -- \\
\hline $18 \mathrm{a}$ & 1 & 1 & 1 & 1 & -- \\
\hline $18 \mathrm{~b}$ & 4 & 4 & 4 & 4 & -- \\
\hline $19 \mathrm{a}$ & 1 & 1 & 1 & 1 & -- \\
\hline $19 b$ & 1 & 1 & 1 & 1 & -- \\
\hline $20 \mathrm{a}$ & 1 & 1 & 1 & 1 & -- \\
\hline $20 \mathrm{~b}$ & 2 & 2 & 2 & 2 & -- \\
\hline $21 \mathrm{a}$ & 4 & 4 & 4 & 4 & -- \\
\hline $21 b$ & 4 & 4 & 4 & 4 & -- \\
\hline $21 \mathrm{c}$ & 4 & 4 & 4 & 4 & -- \\
\hline $22 \mathrm{a}$ & 2 & 2 & 2 & 2 & -- \\
\hline $22 b$ & 2 & 2 & 2 & 2 & -- \\
\hline $22 c$ & 2 & 2 & 2 & 2 & -- \\
\hline $23 a$ & 2 & 2 & 2 & 2 & -- \\
\hline $23 b$ & 4 & 4 & 4 & 4 & -- \\
\hline $23 \mathrm{c}$ & 4 & 4 & 4 & 4 & -- \\
\hline $24 \mathrm{a}$ & 4 & 4 & 4 & 4 & -- \\
\hline $24 \mathrm{~b}$ & 4 & 4 & 4 & 4 & -- \\
\hline $24 \mathrm{c}$ & 2 & 2 & 2 & 2 & -- \\
\hline $25 \mathrm{a}$ & 4 & 4 & 4 & 4 & -- \\
\hline $25 \mathrm{~b}$ & 4 & 4 & 4 & 4 & -- \\
\hline $25 \mathrm{c}$ & 4 & 4 & 4 & 4 & -- \\
\hline $26 a$ & 4 & 4 & 4 & 4 & -- \\
\hline $26 \mathrm{~b}$ & 4 & 4 & 4 & 4 & -- \\
\hline $27 \mathrm{a}$ & 4 & 4 & 4 & 4 & -- \\
\hline $27 b$ & 1 & 1 & 1 & 1 & -- \\
\hline $28 \mathrm{a}$ & 4 & 4 & 4 & 4 & 4 \\
\hline $28 \mathrm{~b}$ & 4 & 4 & 4 & 4 & 4 \\
\hline $29 \mathrm{a}$ & 4 & 4 & 4 & 4 & 4 \\
\hline $29 \mathrm{~b}$ & 4 & 4 & 4 & 4 & 4 \\
\hline Total wells sampled annually & 5 & 5 & 5 & 5 & -- \\
\hline Total wells sampled, 2-year rotation & 8 & 8 & 8 & 8 & -- \\
\hline Total wells sampled, 3-year rotation & 0 & 0 & 0 & 0 & -- \\
\hline Total wells sampled, 4-year rotation & 20 & 20 & 20 & 20 & 4 \\
\hline Total wells sampled north & 33 & 33 & 33 & 33 & 4 \\
\hline
\end{tabular}



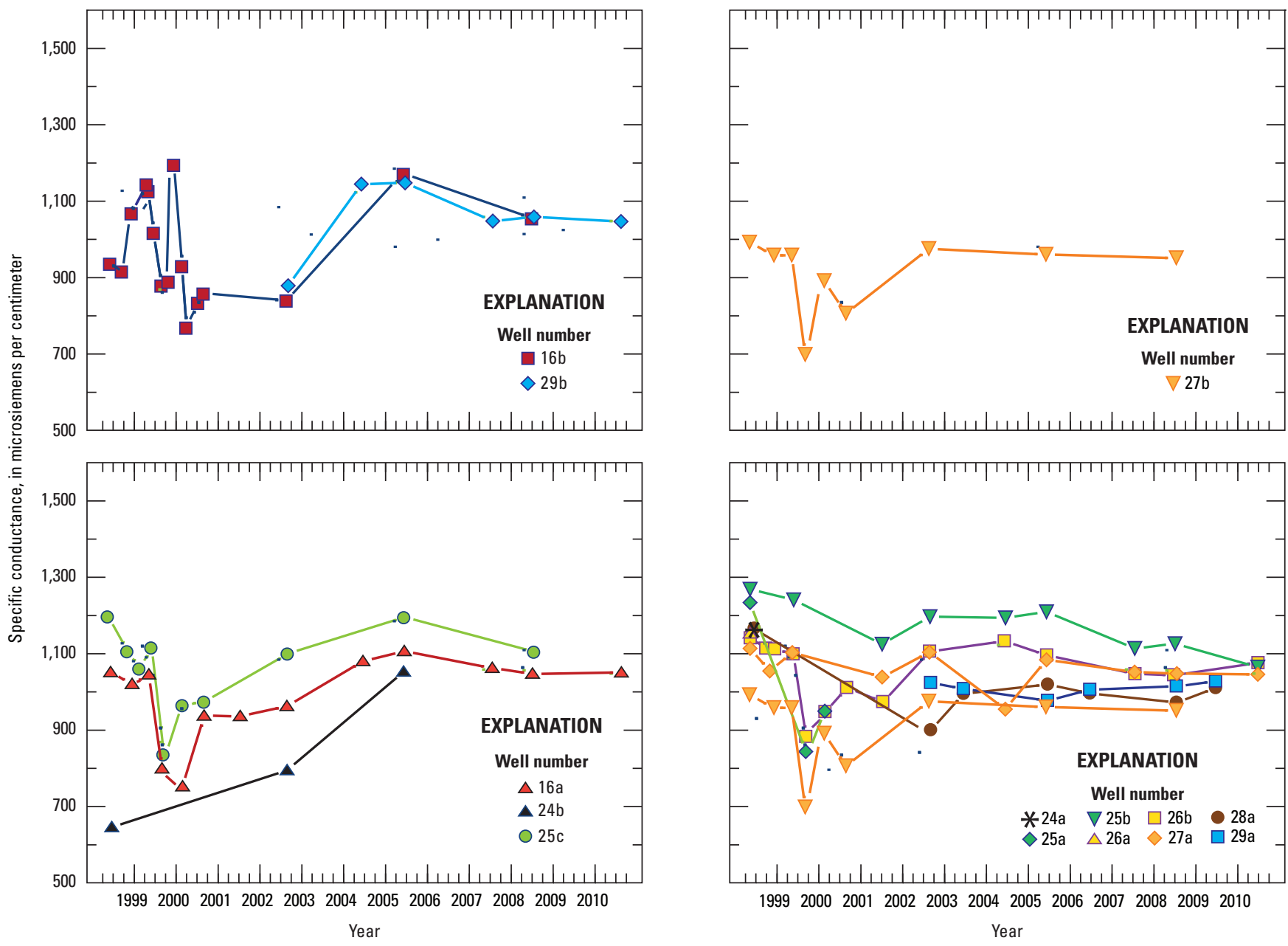

Figure 14. Specific conductance values in wells located north of the Missouri River and with more than 50-year travel times.

for groundwater flow paths to begin to stabilize in response to this period of increased pumpage. Evidence of this is provided by the larger range of specific conductance values during the period 1999 through 2005, after which time values tended to stabilize around 1,100 microseimens per centimeter. It is important that sampling strategies address this inherent variability by including some level of overlap within samples.

The plan provides for consistent, continued assessment of the Missouri River alluvial aquifer in the well-field's vicinity using an existing monitoring well network (table 1). The plan will provide data from 28 of 63 monitoring wells in any given year, while maintaining spatial distribution throughout the study area. Constituents to be sampled (table 4) are based on the need to maintain consistency with previous investigations (Kelly, 2002a, 2010; Kelly and Rydlund, 2006), facilitate long-term data comparison, and provide information related to potential contamination sources. Constituents include the field properties: $\mathrm{pH}$, specific conductance, water temperature, dissolved oxygen, and turbidity; nutrients (nitrogen and phosphorus species), major ions and trace metals; BTEX; and triclosan. Triclosan is included as a surrogate compound to evaluate contamination potential for a suite of wastewater indicator and pharmaceutical compounds (fig. 15). Although the contamination risk for these compounds should be considered slight, concern remains for the potential human health effects associated with exposure, even at low levels, to a number of these compounds (Daughton, 2010; U.S. Government Accountability Office, 2011). A subset of five wells, located downstream from a former oil refinery (wells $1 b$ and $2 b$ ) or adjacent to highway (wells 9c, 10c, and 11c), will be sampled each year for BTEX (table 4). Additionally, four wells (wells 28a, 28b, 29a, and 29b) located adjacent to a construction landfill will be sampled every four years for BTEX. The plan enables managers, planners, and citizens to better understand the nature of source water to the well field and assists with regional groundwater protection strategies. 

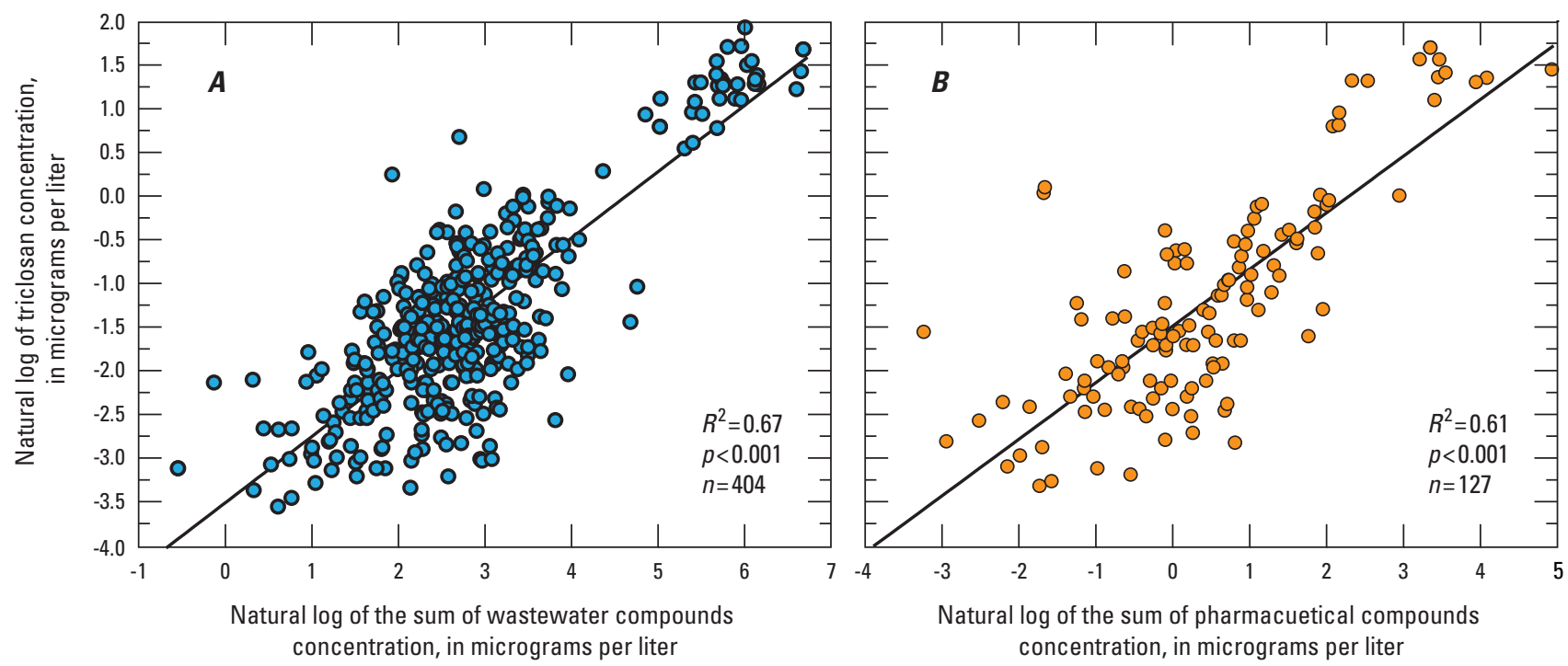

Figure 15. A, Relation between triclosan concentration and organic wastewater, and $B$, pharmacuetical concentrations in water samples collected from the Blue River Basin, 1998 through 2010.

\section{Summary}

A groundwater monitoring plan was designed for the Missouri River alluvial aquifer in the vicinity of the Independence, Missouri well field. The well field provides drinking water for approximately 250,000 residents of Independence, Missouri and Eastern Jackson County, Missouri. Mean groundwater travel times and well-field contributing recharge areas, determined from an existing groundwater flow model, were used together with water-quality data collected from 1997 through 2010 to develop this plan. Key factors addressed in the monitoring plan included source contributions, contributing recharges areas, mean groundwater travel times, and potential contamination sources. The plan provides a consistent monitoring approach for an existing monitoring well network in order to assess water quality and understand future changes that may occur within the 10-year zone of contribution of the well field.

Three factors - well-field pumpage, Missouri River discharge, and aquifer recharge - largely determined groundwater flow and, therefore, source contributions. Mean annual groundwater withdrawals from the Independence well field increased, on average, 15 percent per decade between 1990 through 2010. These withdrawals resulted in a westerly elongation of the contributing recharge area with fairly steep gradients in the vicinity of the Missouri River.

Mean groundwater levels rose in response to increased Missouri River discharge and declined during dry years. The predominate source of groundwater to monitoring and supply wells originated from the Missouri River with most wells discharging greater than 90 percent Missouri River water. Because of that, monitoring and supply-well water quality reflected, to some extent, that of the river. For example, as the mean percent of Missouri River contributions to monitoring wells increased, chloride concentrations also increased. Median chloride concentrations in supply-wells samples were nearly identical to concentrations in Missouri River samples.

Mean groundwater travel times within the contributing recharge area were typically 2 years or less for monitoring wells with flow paths that intersected the Missouri River. Wells within a kilometer of the Independence well field also had similar groundwater travel times. Longer groundwater travel times were typically associated with wells that received most of their recharge from the land surface.

Contaminants that enter the Missouri River (or nearby upstream tributaries) have the potential to enter the alluvial aquifer. Riverbank filtration has been demonstrated to be effective at removing most contaminants as they migrate from the river into the aquifer. Land-use practices, primarily agriculture, and point and nonpoint source contributions from nearby upstream urban centers are also a concern.

The groundwater monitoring plan is based on factors known to affect alluvial water quality. These factors include groundwater source contributions, contributing recharge areas, groundwater travel time, well-field pumpage, Missouri River discharge, land-use practices within the contributing recharge area, and potential contamination sources. Monitoring wells with the shortest groundwater travel times within the contributing recharge area provide an estimate of the maximum potential lead time available for remedial action in the event of aquifer contamination; these wells were selected for annual sampling. These include five monitoring wells that received, on average, more than 90 percent of their recharge from the Missouri River and five wells whose source waters originated almost exclusively from the land surface. The remaining wells, with varying contributing recharge area travel times and intermediate mixtures of source contributions, were chosen to be sampled on 2-, 3-, or 4-year intervals. These staggered intervals help to minimize sample redundancy yet provide 
data from overlapping recharge areas in order to help address inherent variations in aquifer water quality.

The plan details a monitoring strategy designed to evaluate long-term alluvial water quality and assess potential changes in, and threats to, water quality in the vicinity of the Independence well field. This plan provides needed information to better enable water managers, planners, and citizens to protect groundwater quality and preserve natural resources.

\section{References Cited}

Carrara, C., Ptacek, C.J., Robertson, W.D., Blowes, D.W., Moncur, M.C., Sverko, E., and Backus, S., 2008, Fate of pharmaceutical and trace organic compounds in three septic system plumes, Ontario, Canada: Environmental Science and Technology, v. 42, no. 8, p. 2,805-2,811.

Cleveland, W.S., and Devlin, S.J., 1988, Locally weighted regression-An approach to regression analysis by local fitting: Journal of the American Statistical Association, v. 83, p. $596-610$.

Christensen, E.D., Harris, T.E., and Niesen, S.L., 2010, Water quality and ecological condition of urban streams in Independence, Missouri, June 2005 through December 2008: U.S. Geological Survey Scientific Investigations Report 2010-5074, $115 \mathrm{p}$.

Daughton, C.G., 2010, Pharmaceutical ingredients in drinking water-Overview of occurrence and significance of human exposure, in Halden, R.U., ed., Contaminants of emerging concern in the environment-Ecological and human health considerations: ACS Symposium Series, v. 1,048, ch. 2, p. 9-68.

Dickenson, E.R.V, Snyder, S.A., Sedlak, D.L., and Drewes, J.E., 2011, Indicator compounds for assessment of wastewater effluent contributions to flow and water quality: Water Research, v. 45, n. 3, p. 1,199-1,212.

Echols, K.R., Brumbaugh, W.G., Orazio, C.E., May, T.W., Poulton, B.C., and Peterman, P.H., 2008, Distribution of pesticides, PAHs, PCBs, and bioavailable metals in depositional sediments of the Lower Missouri River, USA: Archives of Contamination and Toxicology, v. 55, no. 2, p. 161-172.

Emmett, L.F., and Jeffrey, H.G., 1969, Reconnaissance of the ground-water resources of the Missouri River alluvium between Kansas City, Missouri, and the Iowa border: U.S. Geological Survey Hydrologic Investigations Atlas HA-344, 1 sheet, scale 1:125,000.
Gentile, R.J., Moberly, R.L., and Barnes, S.K., 1994, A geologic cross section of the Missouri River Valley at Kansas City Missouri: Missouri Department of Natural Resources Reports of Investigations, RI-72, Jefferson City, Missouri, 76 p., 1 plate.

Glassmeyer, S.T., Furlong, E.T., Kolpin, D.W., Cahill, J.D., Zaugg, S.D., Werner, S.L., Meyer, M.T., and Kryak, D.D., 2005, Transport of chemical and microbial compounds from known wastewater discharges - Potential for use as indicators of human fecal contamination: Environmental Science and Technology, v. 39, no. 14, p. 5,157-5,169.

Halden, R.U., and Paull, D.H., 2005, Co-occurrence of triclocarban and triclosan in U.S. water resources: Environmental Science and Technology, v. 39, no. 6, p. 1,420-1,426.

Harvey, F.E., 2001, Use of NADP archive samples to determine the isotopic composition of precipitation - Characterizing the meteoric input function for use in ground water studies: Ground Water, v. 39, no. 3, p. 380-390.

Hasan, S.E., Moberly, R.L., and Caoile, J.A., 1988, Geology of greater Kansas City, Missouri and Kansas, United States of America: Bulletin of the Association of Engineering Geologists, v. 25, no. 3, p. 277-341.

Helsel, D.R., and Hirsch, R.M., 1992, Statistical methods in water resources-Studies in environmental science 49: New York, Elsevier Science Publishing Company, 522 p.

Keller, H., Xia, K., and Bhandari, A., 2003, Occurrence and degradation of estrogenic nonyphenol and its precursors in Northeast Kansas wastewater treatment plants: Journal of Hazardous, Toxic, and Radioactive Waste, v. 7, no. 4, p. 203-213.

Kelly, B.P, 1996a, Simulation of ground-water flow and contributing recharge areas in the Missouri River alluvial aquifer at Kansas City, Missouri and Kansas: U.S. Geological Survey Water-Resources Investigations Report 96-4250, $93 \mathrm{p}$.

Kelly, B.P., 1996b, Design of a monitoring well network for the City of Independence, Missouri well field using simulated ground-water flow paths and travel times: U.S. Geological Survey Water-Resources Investigations Report 96-4264, $27 \mathrm{p}$.

Kelly, B.P., 2002a, Groundwater flow simulation and chemical and isotopic mixing equation analysis to determine source contributions to the Missouri River alluvial aquifer in the vicinity of the City of Independence, Missouri, well field: U.S. Geological Survey Water-Resources Investigations Report 2002-4208, 53 p. 
Kelly, B.P., 2002b, Groundwater monitoring plan, water quality, and variability of agricultural chemicals in the Missouri River alluvial aquifer near the City of Independence, Missouri, well field 1998-2000: U.S. Geological Survey WaterResources Investigations Report 2002-4096, 69 p.

Kelly, B.P., 2010, Contributing recharge areas, groundwater travel time, and groundwater quality of the Missouri River alluvial aquifer near the Independence, Missouri well field, 1997-2008: U.S. Geological Survey Scientific Investigations Report 2010-5232, 133 p. (Also available at http://pubs.usgs.gov/sir/2010/5232/.)

Kelly, B.P., and Blevins, D.W., 1995, Vertical hydraulic conductivity of soil and potentiometric surface of the Missouri River alluvial aquifer at Kansas City, Missouri and Kansas-August 1992 and January 1993: U.S. Geological Survey Open-File Report 95-322, 19 p.

Kelly, B.P., and Rydlund, P.H., Jr., 2006, Water-quality changes caused by riverbank filtration between the Missouri River and three pumping wells of the Independence, Missouri, well field 2003-05: U.S. Geological Survey Scientific Investigations Report 2006-5174, 48 p.

Kumar, K.S., Priya, S.M., Peck, A.M., and Sajwan, K.S., 2010, Mass loadings of triclosan and triclocarbon from four wastewater treatment plants to three rivers and landfill in Savannah, Georgia, USA: Archives of Environmental Contaminant Toxicology, v. 58, p. 275-285.

Mid-America Regional Council, 2004, Metro dataline, long-range forecast of the Kansas City Metropolitan Area, accessed April 2011, at http://www.marc.org/metrodataline/ longrangekc.htm.

Missouri Department of Natural Resources, 2009a, Census of Missouri public water systems 2009: Missouri Department of Natural Resources Publication 2368, 362 p., accessed April 2011, at http://www.dnr.mo.gov/pubs/pub2368.pdf.

Missouri Department of Natural Resources, 2009b, Rules of Department of Natural Resources, Division 20-Clean Water Commission, Chapter 7-Water Quality: Title 10 CSR 20.7.031, accessed September 2011, at http://www.sos. mo.gov/adrules/csr/current/10csr/10c20-7.pdf.

Morrissey, D.J., 1989, Estimation of the recharge area contributing water to a pumping well in a glacial-drift, river-valley aquifer: U.S. Geological Survey Water-Supply Paper 2338, $41 \mathrm{p}$.

Pollock, D.W., 1994, User's guide for MODPATH/MODPATH-PLOT, Version 3-A particle tracking post-processing package for MODFLOW, the U.S. Geological Survey finite-difference ground-water flow model: U.S. Geological Survey Open-File Report 94-464, 6 ch.
Rasmussen, T.J., Poulton, B.C., and Graham, J.L., 2009, Quality of streams in Johnson County, Kansas, and relations to environmental variables, 2003-07: U.S. Geological Survey Scientific Investigations Report 2009-5235, 84 p. with appendixes.

Reilly, T.E., and Pollack, D.W., 1993, Factors affecting areas contributing recharge to wells in shallow aquifers: U.S. Geological Survey Water-Supply Paper 2445, 25 p.

Shelver, W.L., Kamp, L.M., Church, J.L., and Rubio, F.M., 2007, Measurement of triclosan in water using a magnetic particle enzyme immunoassay: Journal of Agricultural and Food Chemistry, v. 55, no. 10, p. 3,758-3,763.

Sprague, L.A., Hirsch, R.M., and Aulenbach, B.T., 2011, Nitrate in the Mississippi River and its tributaries, 1980 to 2008-Are we making progress?: Environmental Science and Technology, v. 45, no. 7, p. 7,209-7,216.

Tao, J., Huggins, D., Welker, G., Dias, J.R., Ingersoll, C.G., and Murowchick, J.B., 2009, Sediment contamination of residential streams in the metropolitan Kansas City areaPart I. Distribution of polycyclic aromatic hydrocarbons and pesticide-related compounds: Archives of Environmental Contamination and Toxicology, v. 59, no. 3, p. 352-369.

Taylor, C.J., and Alley, W.M., 2001, Ground-water-level monitoring and the importance of long-term water-level data: U.S. Geological Survey Circular 1217, 68 p.

U.S. Geological Survey, variously dated, National field manual for the collection of water-quality data: U.S. Geological Survey Techniques of Water-Resources Investigations, book 9, chaps. A1-A9, available online at http://pubs.water.usgs. gov/twri9A.

U.S. Geological Survey, 2010, National Water Information System: Water quality samples for Missouri, accessed May 2011, at http://nwis.waterdata.usgs.gov/mo/nwis/qwdata.

U.S. Geological Survey, 2011, Annual Water Data Report, accessed December 2011, at http://wdr.water.usgs.gov/.

U.S. Government Accountability Office, 2011, Environmental Health: Action needed to sustain agencies' collaboration on pharmaceuticals in drinking water: GAO-11-346, 57 p., accessed August 2011, at http://www.gao.gov/products/ GAO-11-346.

Vaccaro, J.J., 2011, River-aquifer exchanges in the Yakima River Basin, Washington: U.S. Geological Survey Scientific Investigations Report 2011-5026, 98 p.

Verstraeten, I.M., Herberer, T., Vogel, J.R., Speth, T., Zuehike, S., and Duennbier, U., 2003, Occurrence of endocrinedisrupting and other wastewater compounds during water treatment with case studies from Lincoln, Nebraska and Berlin, Germany: Journal of Hazardous, Toxic, and Radioactive Waste, v. 7, no. 4, p. 253-263. 
Wilcoxon, F., 1945, Individual comparisons by ranking methods, Biometrics Bulletin, v. 1, n. 6, p. 80-83.

Wilkison, D.H., Armstrong, D.J., and Blevins, D.W., 2002, Effects of wastewater and combined sewer overflows on water quality in the Blue River Basin, Kansas City, Missouri and Kansas, July 1998 to October 2000: U.S. Geological Survey Water-Resources Investigations Report 02-4107, $168 \mathrm{p}$.

Wilkison, D.H., Armstrong, D.J., Norman, R.D., Poulton, B.C., Furlong, E.T., and Zaugg, S.D., 2006, Water quality in the Blue River Basin, Kansas City metropolitan area, Missouri and Kansas, July 1998 to October 2004: U.S. Geological Survey Scientific Investigations Report 2006-5147, $170 \mathrm{p}$.

Wilkison, D.H., Armstrong, D.A., and Hampton, S.A., 2009, Character and trends of water quality in the Blue River Basin, Kansas City Metropolitan Area, Missouri and Kansas, 1998 through 2007: U.S. Geological Survey Scientific Investigations Report 2009-5169, 211 p. 



\section{Appendix 1}

Contributing recharge areas and groundwater flow paths from contributing recharge areas to monitoring wells. 

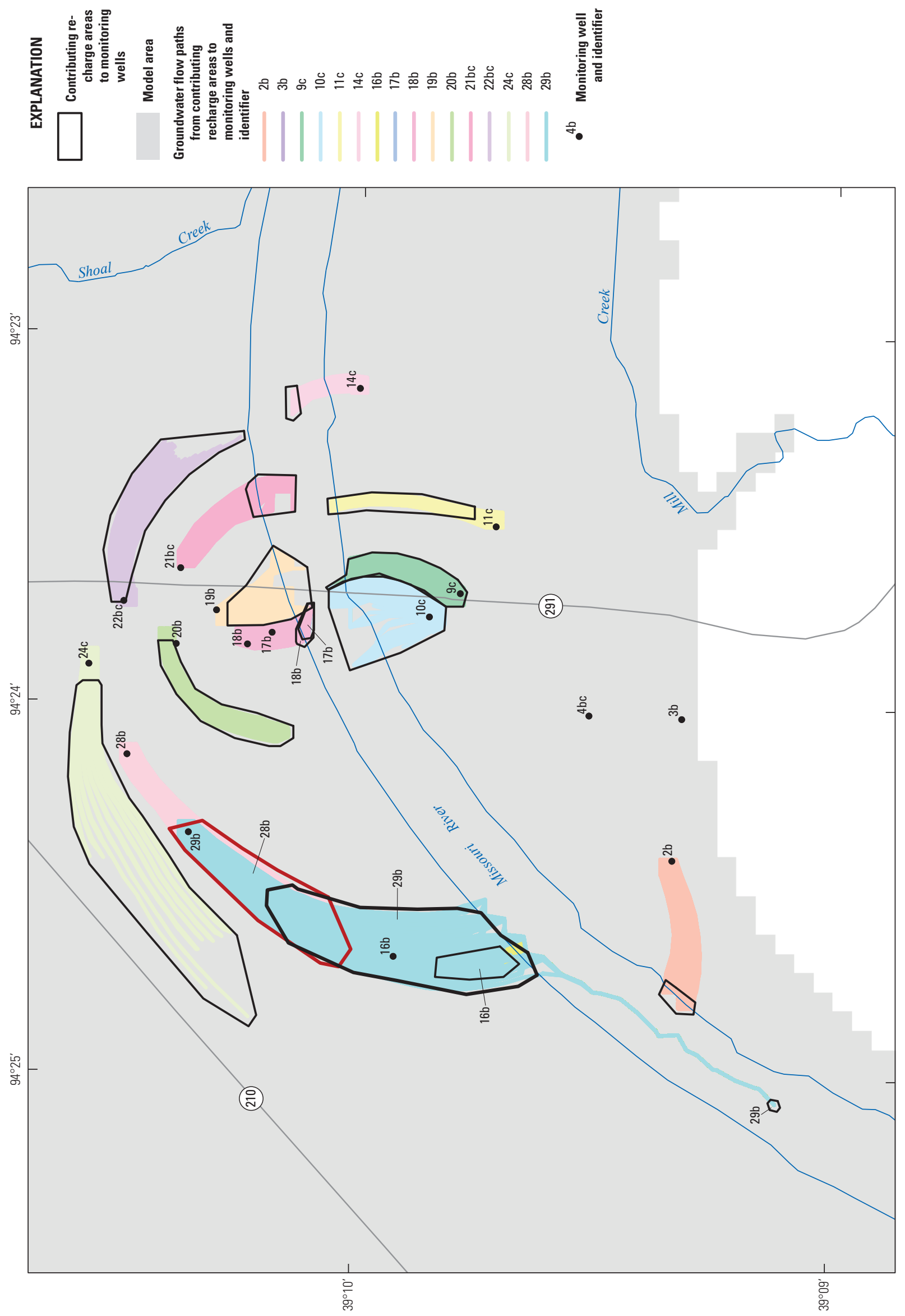


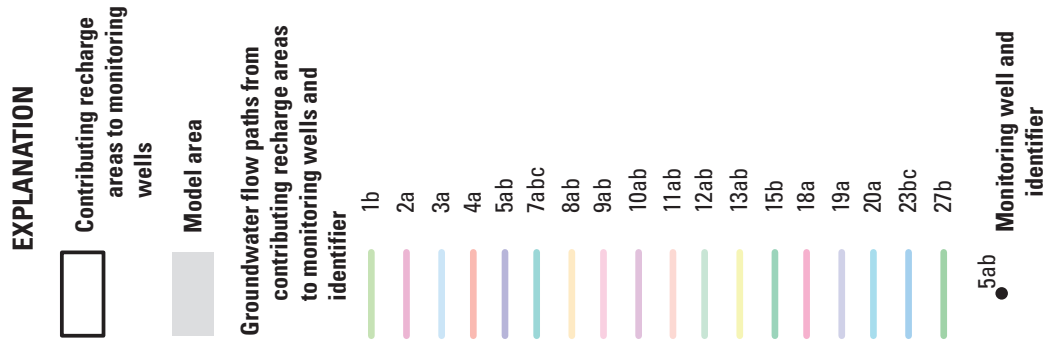

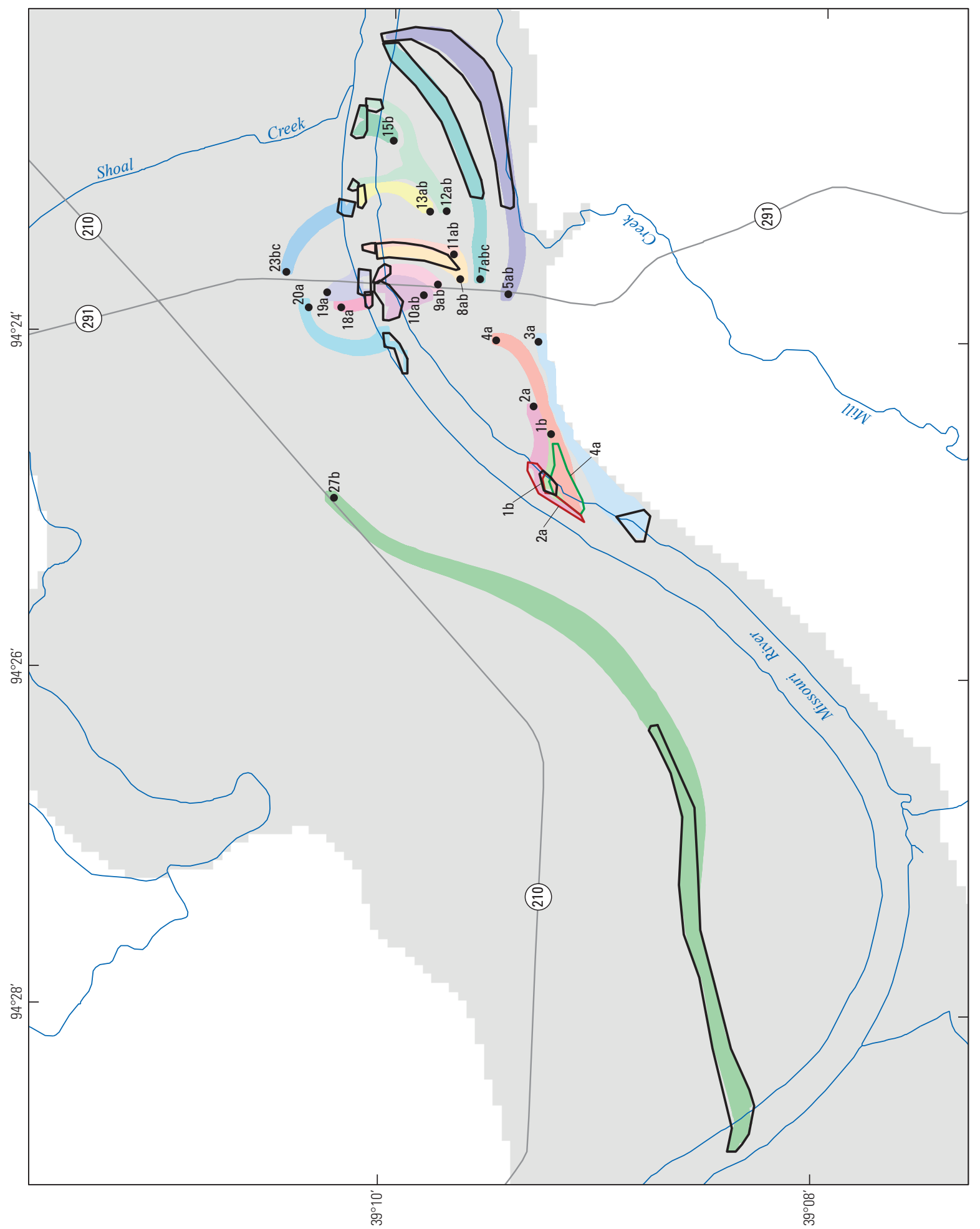



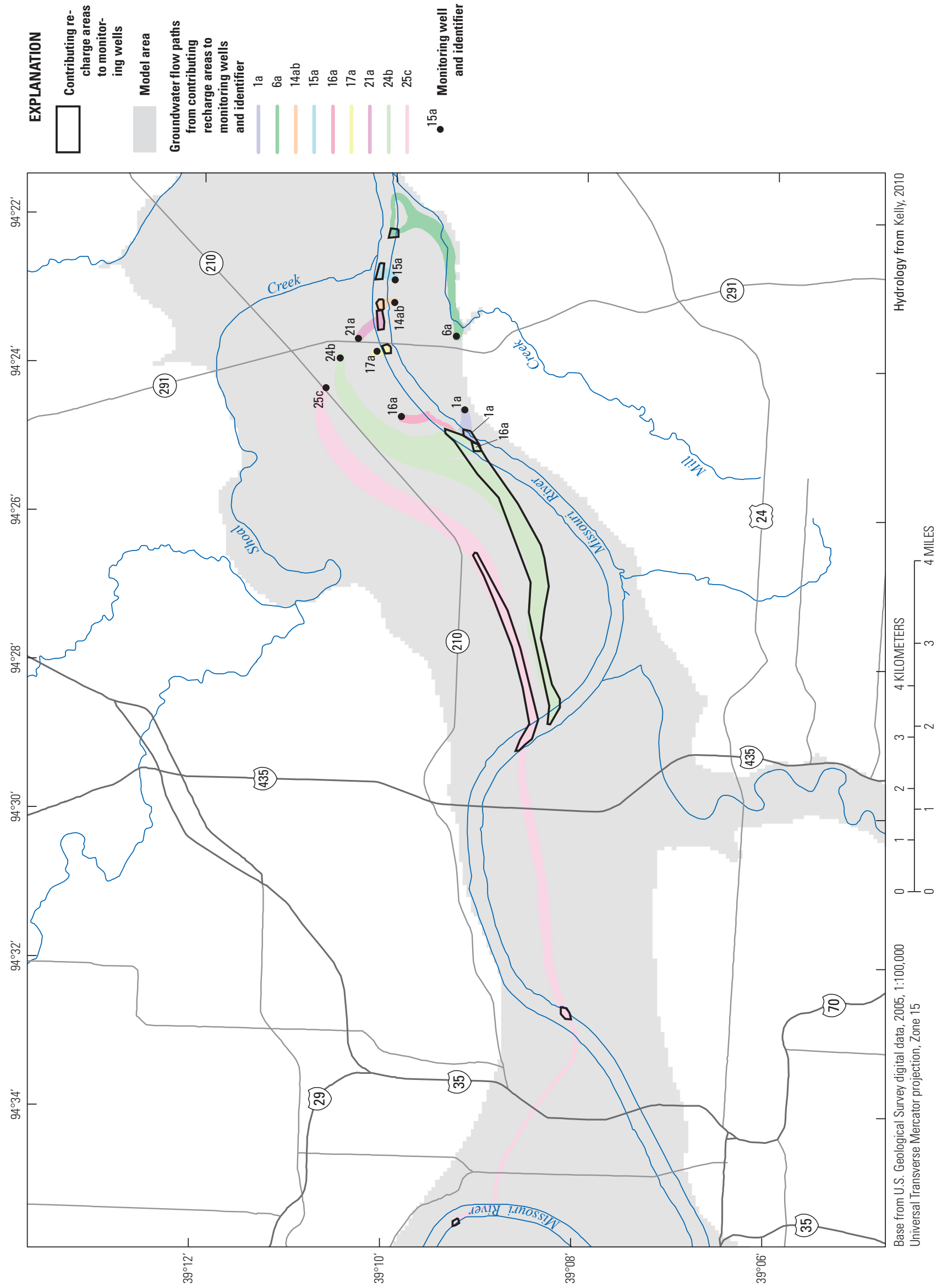

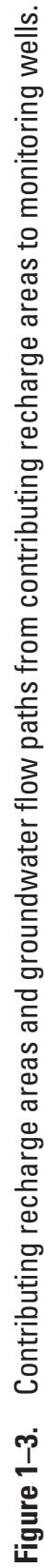



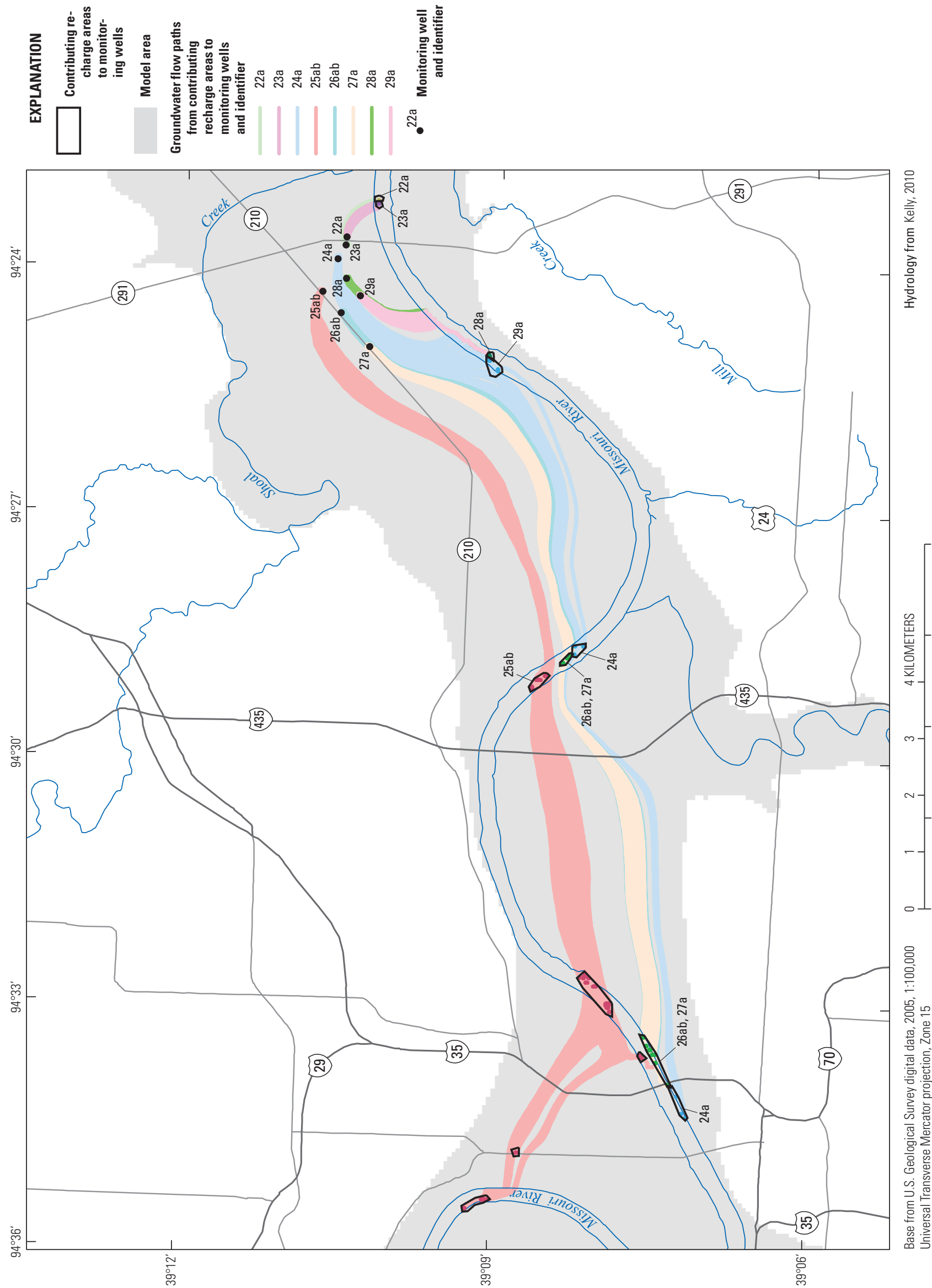
Publishing support provided by:

Rolla Publishing Service Center

For more information concerning this publication, contact: Director, USGS Missouri Water Science Center

1400 Independence Road

Rolla, M0 65401

(573) 308-3667

Or visit the Missouri Water Science Center Web site at: http://mo.water.usgs.gov/ 

